\title{
Spatial pattern of location advantages of ports along the Maritime Silk Road
}

\author{
MOU Naixia ${ }^{1}$, WANG Chunying ${ }^{1}$, CHEN Jinhai ${ }^{2}$, YANG Tengfei ${ }^{3}$, \\ ZHANG Lingxian ${ }^{1}$, LIAO Mengdi ${ }^{1}$ \\ 1. College of Geodesy and Geomatics, Shandong University of Science and Technology, Qingdao 266590, \\ Shandong, China; \\ 2. Navigation College of Jimei University, National-local Joint Engineering Research Center for Marine Navi- \\ gation Aids Services, Xiamen 361021, Fujian, China; \\ 3. Aerospace Information Research Institute, CAS, Beijing 100094, China
}

\begin{abstract}
Location advantages of ports refer to the current developments of ports based on their conditions, such as geographic location, traffic accessibility and hinterland economy, etc., and the spatial pattern of ports' location advantages reflects the spatial distributions, the regularities and the correlations among their conditions for development. A good understanding of the spatial patterns of ports' location advantages can help to better identify the relative advantages of ports, position ports' functions and make strategic plans for development. This paper selected 1259 ports from 63 countries along the Maritime Silk Road as research objects and builds an accessing model to analyze their location advantages on the bases of six factors: the influence of strategic shipping pivot, the competitiveness of port location potential, port network status, the influence of city, the influence of traffic trunk, and road network density in hinterland. The study has the following three findings. Firstly, the location advantages of ports show a "high-low-high" distribution pattern from the west to the east, displaying an obvious "core-periphery" regionalized distribution. Secondly, most ports have high location advantages, mainly located in Strait of Malacca, the United Arab Emirates, northern Mediterranean coastal region and China-Japan region, the top 10 ports are mainly located in Singapore, China, Malaysia and Japan, indicating that the shipping industry in Asia-Pacific region has stepped to the far front of the global competition; slow economic growths, wars, far away from the Belt and Road countries or bad climate have low location advantages, mainly located in African coastal areas, Oceania, Northeast Europe and Russia. Thirdly, compared with the landward location advantages, the seaward location advantages have a higher influence, and different indicators of location advantages have different influences on the evaluation results, the competitiveness of port location potential being the core indicator.
\end{abstract}

Keywords: Maritime Silk Road; location advantages; ports; shipping network; spatial patterns

Received: 2020-03-19 Accepted: 2020-09-11

Foundation: Major Program of National Social Science Fund of China, No.20\&ZD070

Author: Mou Naixia (1973-), Professor, specialized in data mining, big data analysis, tourism and transport geography. E-mail: mounaixia@163.com 


\section{Introduction}

The 21st Century Maritime Silk Road is a great strategic initiative for China and countries along the Maritime Silk Road to seek for cooperation and prosperity. The maritime Silk Road covers more than 60 countries. At present, its trade accounts for over $35 \%$ of global merchandise trade and approximately $30 \%$ of global GDP. By 2050 , it is expected to contribute $80 \%$ to world GDP growth (HKTDC, 2017). It aims at stimulating the development of port cities and the hinterland areas with the help of the port nodes and at building an economic belt for trade and cooperation through the connectivity between ports and ports, ports and cities and ports and hinterlands (Jiang et al., 2018; Tambo et al., 2019). Obviously, ports are key transportation hubs in international trade. Therefore, a quantitative analysis of the ports' location advantages is not only beneficial to the overall understanding of the ports' status of development, but also to the making of different countermeasures according to different location advantages.

Location advantage indicates the degree of spatial connection, formed upon geographic advantages, between the research elements and other elements (Guo et al., 2017), and it is a representation of location quantification, an important indicator reflecting regional economy, development status and potentiality (Xu and Wang, 2009). The traditional analysis of location advantages mainly includes classical location theory and neoclassical location theory. The classical location theory aims at the location choice of single location subject, and uses static partial equilibrium analysis to study the regional spatial effect of location based on the cost and profit $(\mathrm{Xu}, 2004)$. Neoclassical location tends to the location selection problem in the network, and the methods adopted include spatial interaction model, planning model, network theory, system theory and operational research (Ma et al., 2006; Awasthi et al., 2011; Li and Zhong, 2012; Liu et al., 2014). The general equilibrium problem of macro location selection is taken as the main research object, and it is often conducted from the following perspectives including infrastructure levels, economic policies, traffic convenience as well as the demand size of the geographic entity and the attractiveness of the attractive kernel. Among them, for the evaluation of regional dominance of different cities, based on roads and towns, traffic network density of urban units, traffic trunk lines and other cities and towns are selected as the evaluation indexes affecting the location superiority degree. And most of the models used are gravity model or weighted gravity model (Páez et al., 2012). Wang et al. (2016a) utilized a vector-based synthetic method to reveal, based on traffic accessibility and road network density, the difference in traffic advantages between southern and northern Beijing. Xu and Wang (2009) analyzed the location advantages of Zezhou County through traffic network density, the influence of traffic trunk and the influence of city, etc., and proved the rationality and feasibility of this model. From the perspective of spatial pattern, Lu and Chen (2008) employed gravity model to study the influences of administrative division and traffic on a region to assess the location advantages of every county and city in Hubei province and then offer exact suggestions to the planning and development of the city. In conclusion, there is a relatively perfect evaluation of the urban regional location advantages, mainly through the administrative division elements and traffic factors. These studies provide a strong basis for further exploration of port location advantages. 
Port location is the primary condition to be considered for port planning and construction, and it is also an important factor representing the importance of ports and the connectivity of shipping network. Port location not only refers to the geographic location of a port, but also covers the spatial connections between a port and the external objects. In the early 1940s, German scholar Gautz put forward "The Theory of Seaport Location", opening the prelude to the study of modern port area. By using Weber's idea of industrial location theory, he connected the port with the hinterland, and believes that the location of seaport construction should conform to the principle of minimum total cost, so as to explore the optimal location of the port (Yang, 1997). In 1965, British geographer Bird put forward the famous model "Anyport" from the relationship between port facilities construction and port location by studying the development process of major ports in Britain (Bird, 1965). Hoyle and Pinder carried out researches on ports and industrialization, and compiled the book "City Port Industrialization and Regional Development". And the main theme of this book is the interaction of port development, industrial development, urban development and regional development (Hoyle and Pinder, 1981).

As for the relationship between port and hinterland, Patton and Morgan et al. studied the relationship between ports and hinterland, and the results showed that hinterland plays a decisive role in the formation and development of ports (Patton, 1958; Morgan, 1958). Researches on hinterland competition between ports were also expanded, involving port accessibility, railway connectivity, labor costs, and land availability (Mayer, 1978). As for some researches on the relationship between ports and cities and their development model, in view of the "waterfront renaissance movement" in the 1990s, McCalla believes that the condition for the land on both sides of the coastline to become waterfront is that the port continues to carry out production activities within a certain period of time (McCalla, 1983). And most scholars define waterfront as a certain area connecting port and urban area (Hall, 1991). In addition, many scholars studied the evolution of port space. For example, Taaffeet et al. (1963) studied the evolution characteristics of port spatial structure from the traffic connection between port and hinterland. To sum up, the researches on port location started from the construction of port location, and constantly expanded the research scope of port and other regions, but deficiencies still exist:

1) As for the research object and background, the researches mainly focus on the ports and regions of developed countries, but less on the port location of developing countries. 2) In terms of research elements, most of the researches on ports and regions are carried out only from the perspective of land transportation or marine trade, while there are few researches on the combination of inland regional transportation, port hinterland and maritime transportation network and maritime technology. 3) In the light of research methods, the researches of port location mostly adopt the way of qualitative description, which lacks the accuracy and depth of analysis to a certain extent. Although the researches on econometric geography continue to deepen and penetrate into many disciplines, the researches on the quantification of port location are still less. Hoyle and Hilling summarize the research contents of port location in modern times in the book Harbor System and Spatial Changes (Greenwood et al., 1985), as is shown in Figure 1. 


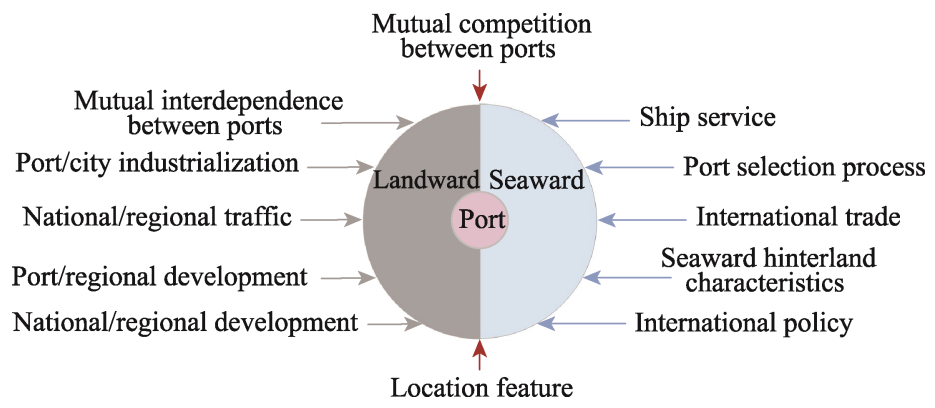

Figure 1 Contents of related studies on port location

The location of modern ports has been studied in both breadth and depth. To date, relative studies have investigated, from different perspectives, the factors affecting port location, including traffic accessibility of a port (Wang et al., 2017; Wang et al., 2018a), governance of logistics development (Raimbault, 2019; Tadić et al., 2019), shipping network features (Sun and Zheng, 2016; Wang and Zhu, 2017; Peng et al., 2018a), competition and cooperation relations (Merkel, 2017; Kavirathna et al., 2019) and the interactions among hinterlands (Van den Berghe et al., 2018; Moura et al., 2019), and more others. The researches on port location advantages can be divided into two aspects: land and sea. The sea location advantages involve three aspects, including the own geographical location of ports, the competition of goods sources between ports, and the control power of maritime network. Wang et al. (2018b) analyzed the correlation between port location and strategic position, believing that a port will exert more influence on the trades and the transportation of strategic supplies within its area if it belongs to a strategic hub, a strategic corridor or a strategic sea, which proves that the port location condition is related to the control power of maritime network. An et al. (2000) analyzed the development situation of large-scale development and fierce competition of container ports in the world. It is considered that the rise of Asian container ports is a historical trend. Based on the analysis of the formation and development mechanism and development mode of container hub ports, this paper discusses the correlation between the location conditions of China's container hub ports and the competitiveness of goods sources, and verifies the relationship between the location conditions of ports and the cargo between ports. Dong et al. (2006), based on the classic location theory, applied the location potential concept model to the port location research, and found that Wenzhou Port is in a competitive disadvantage in the southwest of Zhejiang Province, proving that the port location condition is related to the source competition between ports; Mou et al. (2018b) analyzed the correlations and competitions among the ports along the Maritime Silk Road in shipping network through degree indicator, the mode of spatial arrangement and Herfindahl-Hirschman Index. It is found that a small number of ports have obvious competitive advantages in the region, forming a maritime network pattern with grade differences, which verifies that the port location conditions are related to the control power in the maritime network. In addition, land-based location advantages involve two aspects of city and traffic. Ducruet et al. (2018) analyzed the relation between city sizes and maritime transport flows and found that relatively larger cities have greater location advantages and thus occupy a 
more remarkable position in global shipping network, which verifies the correlation between port location and hinterland cities. Peng (2013) used locational potential model to do a quantitative analysis on the transportation accessibilities of Shanghai Port, Ningbo Port and Zhoushan Port to their hinterlands, and find that the three ports are in a situation of tripartite confrontation, which proves the correlation between port location and traffic feasibility. Jiang et al. (2015) discussed the port connectivity of global container shipping, and found that the ports of Singapore and Shanghai have the highest connectivity in terms of transportation capacity, which verifies the correlation between port location conditions and port connectivity. Table 1 is the main literature review of this study, focusing on the problems in focus, important findings and related indicators in this paper. It can be seen that there is a lack of a perfect evaluation system for the location advantages degree of ports. One of the important reasons is that ports, as the hub connecting land and ocean, are divided into land and ocean in geography (Wang, 2008). However, the traditional evaluation methods for the location advantages degree of inland cities can not fully reflect the comprehensive location advantages of ports in both land and sea directions. For example, Mou et al. (2018a) and Peng et al. (2018b) conducted quantitative assessments on the location advantages of the important ports along the Maritime Silk Road, and they added Complex Network analysis and geographic location analysis to the traditional way of assessment, but deficiencies still exist. Firstly, the samples of ports are not enough, so the distribution feature of all ports' location advantages will seem indefinite if it is conjectured only from the important ports along the Maritime Silk Road. Secondly, from seaward aspect, the influences brought by port-to-port trade frequency, shipping advantages in strategic sea, port sizes and throughputs, etc. are ignored. Thirdly, from landward aspect, the influences brought by the differences in hinterland economic levels and inland transportations within port areas are also ignored.

Existing shipping network research uses ship shipping schedules provided by such resources as Containerisation International, Barry Rogliano Salles (Alphaliner database), company websites, and journals (Wang, 2016b; Kojaku et al., 2019). These data are mostly from customs data and certain lag exists, and research is mostly concentrated on the container network (because the data is easy to obtain due to the fixed schedule for container transportation), so this paper uses ship real-time positioning data (Robards et al., 2016), such as Lloyd's List, Lloyd's Register of Shipping, Automatic Identification System (AIS) data (Kosowska-Stamirowska et al., 2016). AIS data of ships is similar to GPS data of vehicles, both aiming to accurately grasp the real traffic situation by collecting a large amount of data (Liu et al., 2020). Ducruet et al. (2015) conducted some tests on the accuracy of Lloyd data and found that it covers most of the maritime transport information. The extracted data is sufficient to represent global maritime network traffic. Therefore, this paper uses AIS data from Lloyd's Register of Shipping. It contains three cargo ship transportation information of container, oil tanker and dry bulk carrier to more accurately reflect the importance and competitiveness of the port in the entire shipping network. Therefore, this paper comprehensively considers all aspects of land and sea, and constructs a schematic diagram of location advantages of ports to dig out a more comprehensive assessment of the location advantages, as shown in Figure 2. 
Table 1 Summary of the main research on location advantages

\begin{tabular}{|c|c|c|c|}
\hline Reference & Research content & Conclusions & $\begin{array}{l}\text { Related } \\
\text { indicator }\end{array}$ \\
\hline $\begin{array}{l}\text { Wang et } \\
\text { al., 2018b }\end{array}$ & $\begin{array}{l}\text { The correlation between port location and } \\
\text { strategic position }\end{array}$ & $\begin{array}{l}\text { Port will exert more influence on the } \\
\text { trades and the transportation of strategic } \\
\text { supplies within its area if it belongs to a } \\
\text { strategic hub, a strategic corridor or a } \\
\text { strategic sea }\end{array}$ & $\begin{array}{l}\text { The influence } \\
\text { of strategic } \\
\text { shipping pivot }\end{array}$ \\
\hline $\begin{array}{l}\text { An et al., } \\
2000\end{array}$ & $\begin{array}{l}\text { Analyze the development situation of large- } \\
\text { scale container ports and fierce competition } \\
\text { in the world }\end{array}$ & $\begin{array}{l}\text { Discuss the blueprint of China's conta- } \\
\text { iner hub ports, and verify the correlation } \\
\text { between port location conditions and } \\
\text { cargo source competitiveness }\end{array}$ & $\begin{array}{l}\text { The competi- } \\
\text { tiveness of } \\
\text { port location } \\
\text { potential }\end{array}$ \\
\hline $\begin{array}{l}\text { Peng et al., } \\
2018 \mathrm{~b}\end{array}$ & $\begin{array}{l}\text { Use weighted degree centrality, weighted } \\
\text { closeness centrality and weighted between- } \\
\text { ness centrality to evaluate the networks } \\
\text { status of ports }\end{array}$ & $\begin{array}{l}\text { Network status index plays a decisive } \\
\text { role in the comprehensive competitive- } \\
\text { ness of a port: the higher a port's ranking } \\
\text { in network status, the stronger its com- } \\
\text { prehensive competitiveness }\end{array}$ & $\begin{array}{l}\text { Port network } \\
\text { status }\end{array}$ \\
\hline $\begin{array}{c}\text { Lu and } \\
\text { Chen, } 2008\end{array}$ & $\begin{array}{l}\text { Evaluate the location advantages of Wuhan } \\
\text { city circle based on the gravity scale of ad- } \\
\text { ministrative division elements and traffic } \\
\text { factors }\end{array}$ & $\begin{array}{l}\text { Wuhan city circle has significant location } \\
\text { advantages compared with other counties } \\
\text { and cities in the province }\end{array}$ & $\begin{array}{l}\text { The influence } \\
\text { of city }\end{array}$ \\
\hline $\begin{array}{l}\text { Jin et al., } \\
2008\end{array}$ & $\begin{array}{l}\text { Select the density of traffic network, the } \\
\text { influence degree of traffic trunk line and the } \\
\text { degree of location advantages to identify the } \\
\text { traffic location advantages of each regional } \\
\text { unit in China from the three dimensions of } \\
\text { point, line and surface }\end{array}$ & $\begin{array}{l}\text { The distribution of regional traffic ad- } \\
\text { vantage in China is "partial normal" }\end{array}$ & $\begin{array}{l}\text { The influence } \\
\text { of traffic trunk } \\
\text { and road } \\
\text { network } \\
\text { density in } \\
\text { hinterland }\end{array}$ \\
\hline $\begin{array}{l}\text { Yang et al., } \\
\quad 2008\end{array}$ & $\begin{array}{l}\text { Select the length of national railway, inland } \\
\text { waterway and highway to quantitatively } \\
\text { analyze the development of China's inter } \\
\text { provincial comprehensive transportation }\end{array}$ & $\begin{array}{l}\text { There are serious differences of the } \\
\text { transportation development in China }\end{array}$ & $\begin{array}{l}\text { Road network } \\
\text { density in } \\
\text { hinterland }\end{array}$ \\
\hline
\end{tabular}

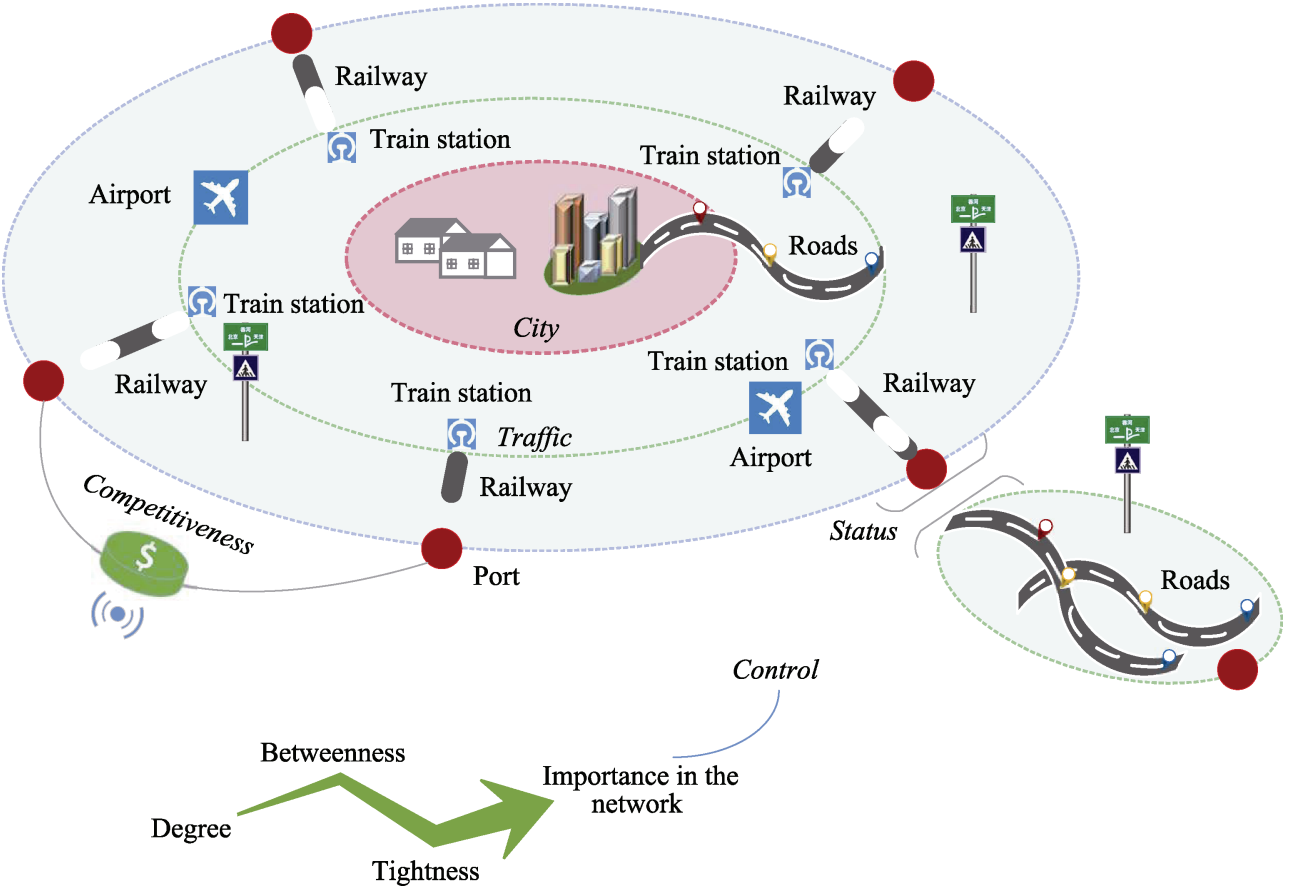

Figure 2 The schematic diagram of location advantages of ports 
In view of this, this paper selects 1259 ports from 63 countries along the Maritime Silk Road on the basis of Automatic Identification System (AIS) data and the latest statistical data. From the perspective of spatial patterns, and based on existing research, this study further considers the strategic positions of ports, the economic levels in hinterlands, the throughputs of ports, shipping network status, and so on, completes the measurement by seaward and landward indexes, and adds some assessment indexes, such as the influence of strategic shipping pivot, the competitiveness of port location potential and the port network status, etc., to evaluate the location advantages of all chosen ports. Therefore, it is more specific and scientific in serving port planning and location choice, infrastructure construction in port areas and hinterlands as well as investment risk prediction.

\section{Data and methods}

\subsection{The research regions and data}

The 21st Century Maritime Silk Road is mainly divided into three lines: the west line, the east line and the north line. The west line starts from South China Sea and goes through Indian Ocean to Asian, European and African regions. The east line starts from the southeast costal region in China and goes through Indonesia to South Pacific region. The north line starts from the ports in eastern China coastal regions and goes through South Korea and Japan to Eastern Russia. The distribution of the research regions and ports is shown in Figure 3, and the data sources are shown in Table 2.

(1) The "World Port Index" includes information such as the index number of the port,

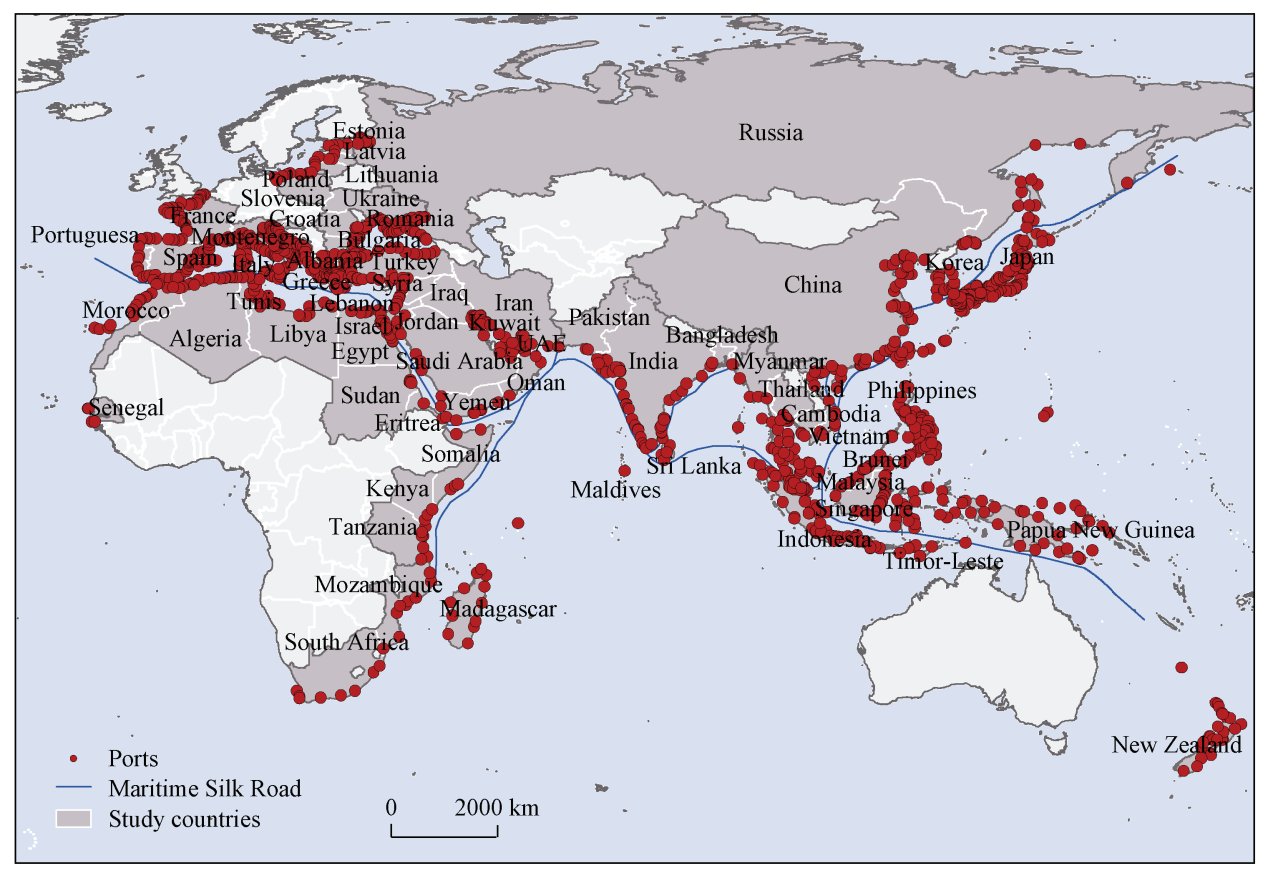

Figure 3 The study countries and ports 
country, latitude and longitude, port type, and port size. The attributes required for this study include port latitude and longitude, and port size. The port size includes four types of large port, medium port, small port and very small port.

(2) Through spatial position matching, ship type identification, shipping index tracking and other methods, this paper extracted 22,849 ships, 1432 ports, 293,028 container OD data, 218,071 bulk OD data and 361,954 oil OD data from the global AIS data from January 1 to December 31, 2014. And finally selected 1259 ports and 186,118 container OD data, 123,052 bulk OD data and 231,410 oil OD data within the scope of the Maritime Silk Road for the study field.

(3) The geographic location of the national capital is obtained, the first-level administrative center and the second-level administrative center in the OpenStreetMap, and combine with the vector road network information of the railway station, highway and traffic trunk is combined to calculate the shortest distance between the ports of each country and the above three cities.

Table 2 The data source

\begin{tabular}{|c|c|c|}
\hline Assessment index & Data & Data sources \\
\hline $\begin{array}{l}\text { The influence of } \\
\text { strategic shipping } \\
\text { pivot }\end{array}$ & $\begin{array}{l}\text { The distribution of strategic } \\
\text { hubs, strategic corridors and } \\
\text { strategic sea }\end{array}$ & $\begin{array}{l}\text { See reference (Wang et al., 2018b) ( } 44 \text { strategic hubs, } 7 \\
\text { strategic corridors and } 3 \text { strategic seas are in worldwide) }\end{array}$ \\
\hline $\begin{array}{l}\text { The competitiveness } \\
\text { of port location } \\
\text { potential }\end{array}$ & $\begin{array}{l}\text { The hinterland economic } \\
\text { data, the throughputs of } \\
\text { ports, port sizes }\end{array}$ & $\begin{array}{l}\text { The economic data is from https://www.yidaiyilu.gov.cn/ } \\
\text { and http://www.worldbank.org/; The throughputs data of } \\
\text { ports are from http://www.worldbank.org/ and } \\
\text { http://data.stats.gov.cn/gjwz.htm; Ports' sizes are from } \\
\text { World Port Index (http://www.nga.mil/) }\end{array}$ \\
\hline Port network status & AIS data & Global AIS data of 2014 \\
\hline The influence of city & City information & From OpenStreetMap (http://www.openstreetmap.org/) \\
\hline $\begin{array}{l}\text { The influence of } \\
\text { traffic trunk }\end{array}$ & Road network information & From OpenStreetMap (http://www.openstreetmap.org/) \\
\hline $\begin{array}{l}\text { Road network } \\
\text { density in hinterland }\end{array}$ & $\begin{array}{l}\text { The length of road network, } \\
\text { hinterland areas }\end{array}$ & $\begin{array}{l}\text { From https://www.yidaiyilu.gov.cn/ and } \\
\text { https://www.cia.gov/index.html }\end{array}$ \\
\hline
\end{tabular}

Note: Regardless of the impact of hinterland cross and mutual competition, the port hinterland is defined as the entire administrative division of the country to which the port belongs.

\subsection{Methods}

This paper is concerned with both seaward and landward factors. Seaward assessment indexes include the influence of strategic shipping pivot, the competitiveness of port location potential and port network status, while landward assessment indexes involve the influence of city, the influence of traffic trunk and road network density in hinterland. Based on the indexes, the paper builds a comprehensive assessment model to fully reveal the location advantages of ports and the features of their spatial patterns. The evaluation index system is shown in Figure 4.

2.2.1 Measuring method with seaward indexes

(1) The influence of strategic shipping pivot

Strategic shipping pivot is a port node that plays a leading and restraining role in the smooth and normal operation of the maritime network. It is usually located in the places 
where many routes must pass or where there are conflicts of interests, including strategic hub, strategic corridor or strategic sea, whose influence reflects the position and role of ports in the global maritime network. Through the geographical location relationship between ports and strategic shipping pivot, the influence of strategic pivot of each port can be obtained by classification score assignment. Among them, the shipping strategic hub refers to the important port nodes, and these port nodes can gather and connect many routes to realize the distribution, transshipment and reorganization of goods. Strategic shipping corridors converge with major global routes, and ships are frequent and intensive. The shipping strategic sea is an important sea area connected by the strategic hubs and the strategic corridors, which can highly control the transportation of strategic materials. If the port is located within or close to the strategic pivot, its location advantages in the maritime network will be most significant (Wang et al. (2018b). The assessment model of the influence of strategic shipping pivot is as follows:

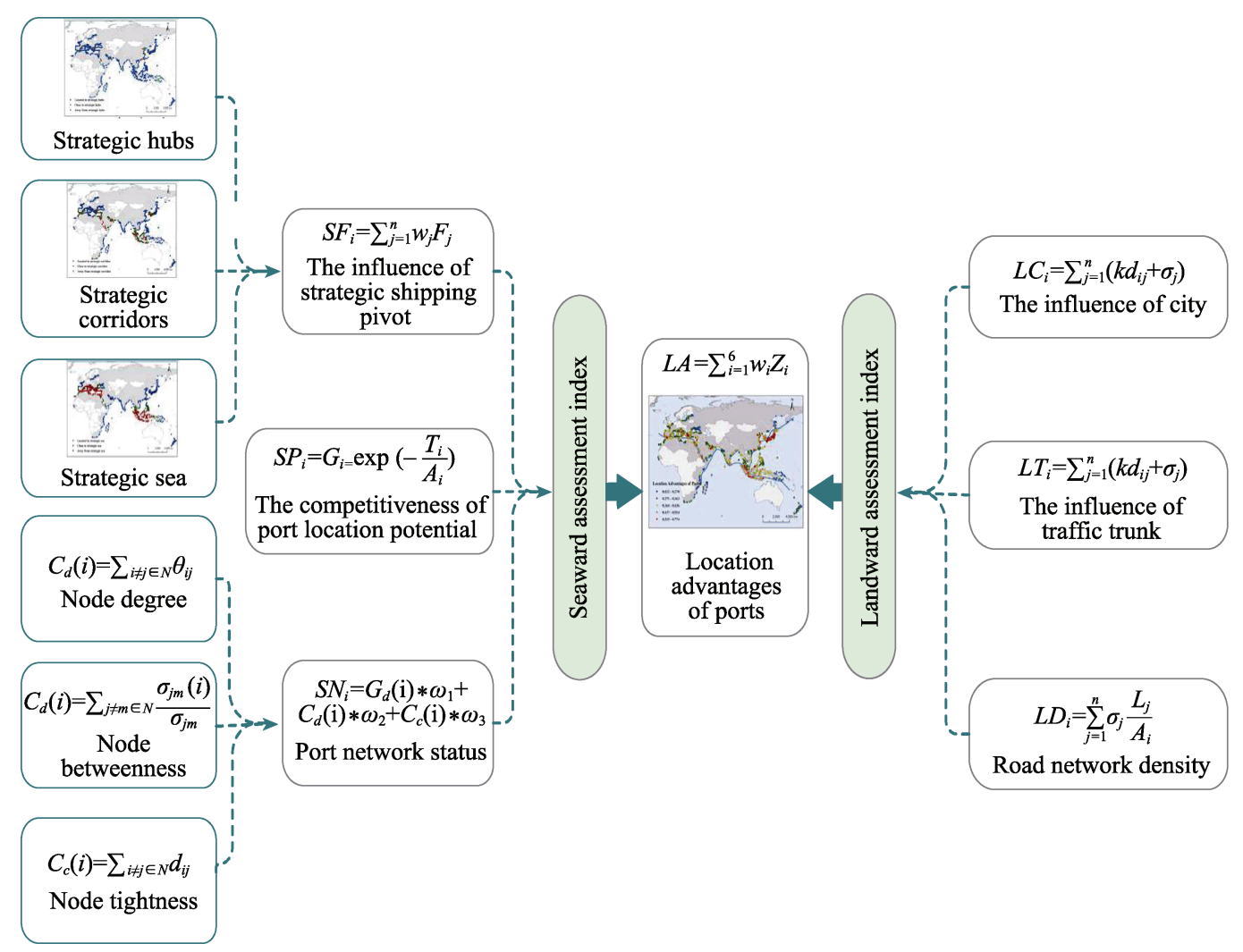

Figure 4 The evaluation index system of location advantages of ports

$$
\begin{gathered}
S F_{i}=\sum_{j=1}^{n} w_{j} F_{j} \\
S F_{i}^{\prime}=\left(S F_{i}-S F_{\text {min }}\right) /\left(S F_{\text {max }}-S F_{\text {min }}\right)
\end{gathered}
$$

where, $S F_{i}$ is the influence of strategic pivot of port $i ; n$ is the number of assessment index; $W_{j}$ is the weight value of each assessment index; $F_{j}$ is the score of each assessment index. 
$S F_{i}{ }^{\prime}$ is the normalized influence of strategic pivot of port $i$, while $S F_{\max }$ and $S F_{\min }$ refer to the maximum and minimum values of the influence of strategic pivot of all ports.

(2) The competitiveness of port location potential

"Location potential" is introduced from physics, and it reflects the opportunity and possibility of mutual influences among entities within the same regional system but in different positions (Chen et al., 2018). "Port location potential" refers to the ability of a location to enable a port with higher benefits or utility. And the competition for sea and land sources is the main contents of the competition between related ports, in other words, "The competitiveness of port location potential" is used to analyze some opportunities of the ports to attract cargo ships and possibilities of attracting hinterland sources. For ports and cargo sources, the ability to attract cargo sources is related to factors such as the economic development and throughput per unit area. Therefore, the location potential model is used to calculate the relationship between the ports and the hinterland's economy and its own throughput capacity. The assessment model of the competitiveness of port location potential is as follows:

$$
\begin{gathered}
S P_{i}=G_{i} \exp \left(-T_{i} / A_{i}\right) \\
S P_{i}^{\prime}=\left(S P_{i}-S P_{\text {min }}\right) /\left(S P_{\text {max }}-S P_{\text {min }}\right)
\end{gathered}
$$

where, $S P_{i}$ is the competitiveness of location potential of port $i$; $G_{i}$ indicates the hinterland economic level of port $i$ (i.e., GDP, and the unit is 100 million USD); $T_{i}$ is the throughput of port $i$, which is the official statistical data for evaluating port productivity, and the unit used in this article is 100 million tons; and $A_{i}$ is the size of port $i$, which is divided by the National Geospatial Intelligence Agency [1] on the basis of port area, port infrastructure and terminal space including large, medium, small, and very small. $S P_{i}{ }^{\prime}$ is the normalized competitiveness of location potential of port $i$, while $S P_{\max }$ and $S P_{\min }$ are the maximum and minimum values of the competitiveness of location potential of all ports.

(3) Port network status

Port network status refers to a port's ability to control the global shipping network. Ports of different levels or classes have different significances to and play different roles in the global shipping network; consequently, only using the number of shipping lines (node degree) is not adequate to reflect a port's status and importance in shipping network. From a complex network, this paper chooses topologic features, such as node degree, node betweenness and node tightness, etc., to investigate the overall structure of the shipping network along the Maritime Silk Road and to fully mirror the node natures of the ports to be studied in shipping network (Viljoen and Joubert, 2016). The assessment model of port network status is expressed as:

$$
\begin{gathered}
C_{d}(i)=\sum_{i \neq j \in N} \theta_{i j} \\
C_{b}(i)=\sum_{j \neq m \in N} \frac{\sigma_{j m}(i)}{\sigma_{j m}} \\
C_{c}(i)=\sum_{i \neq j \in N} d_{i j} \\
S N_{i}=C_{d}(\mathrm{i}) * \omega_{1}+C_{b}(\mathrm{i}) * \omega_{2}+C_{c}(\mathrm{i}) * \omega_{3}
\end{gathered}
$$




$$
S N_{i}^{\prime}=\left(S N_{i}-S N_{\min }\right) /\left(S N_{\max }-S N_{\min }\right)
$$

where, $S N_{i}$ is the network status of port $i ; C_{d}, C_{b}$ and $C_{c}$ are node degree, node betweenness and node tightness respectively; $\omega_{1}, \omega_{2}$ and $\omega_{3}$ are the weight values of the three indexes; $N$ is the aggregation of port nods; and $i, j$ and $m$ refer to the different ports in the aggregation. $\theta_{i j}$ represents the connection between port $i$ and port $j$; if they are connected, then $\theta_{i j}=1$, otherwise $\theta_{i j}=0 . \sigma_{j m}$ is the number of the shortest paths between port $j$ and port $m ; \sigma_{j m}(i)$ is the number of these shortest paths that pass port $i ; d_{i j}$ refers to the shortest distance between port $i$ and port $j . S N_{i}{ }^{\prime}$ is the normalized network status of port $i$, while $S N_{\max }$ and $S N_{\min }$ are the maximum and minimum values of network status of all ports.

\subsubsection{Measuring method with landward indexes}

(1) The influence of city

The influence of city means the comprehensive influence brought to a port by its hinterland cities with different development levels. For the ports and cities, the impact of hinterland cities on ports is related to the level of urban development and traffic distance, and the intensity of the impact attenuates as the distance increases. To calculate the relationship between the port and the capital, first-level administrative center and second-level administrative center, the evaluation model adopted is as follows:

$$
\begin{gathered}
L C_{i}=\sum_{j=1}^{n}\left(k d_{i j}+\sigma_{j}\right) \\
L C_{i}^{\prime}=\left(L C_{i}-L C_{\min }\right) /\left(L C_{\max }-L C_{\min }\right)
\end{gathered}
$$

where, $L C_{i}$ is the influence of city of port $i ; k$ is attenuation coefficient $(k<0) ; d_{i j}$ is the shortest traffic distance between port $i$ and city $j$; and $\sigma_{j}$ is the weight value of the city that has a positive correlation with the development of the city, and the higher the city development level is, the greater the weight value is. $L C_{i}{ }^{\prime}$ is the normalized influence of city of port $i$, while $L C_{\max }$ and $L C_{\min }$ are the maximum and minimum values of the influence of city of all ports.

(2) The influence of traffic trunk

The influence of traffic trunk refers to the comprehensive influence brought to a port by different levels of roads in its hinterland. The traffic arteries include railway station, highway, trunk, airport, etc. By analyzing the distance between the port area and the traffic arterial line, the convenience of the port and other spatial entities can be evaluated. The influence of traffic arteries on spatial entities conforms to the rule of distance attenuation, and the degree of influence is 0 if it exceeds its influence range. The assessment model of the influence of traffic trunk is as follows:

$$
\begin{gathered}
L T_{i}=\sum_{j=1}^{n}\left(k d_{i j}+\sigma_{j}\right) \\
L T_{i}^{\prime}=\left(L T_{i}-L T_{\min }\right) /\left(L T_{\max }-L T_{\min }\right)
\end{gathered}
$$

where, $L T_{i}$ is the influence of traffic trunk of port $i$; $k$ is attenuation coefficient $(k<0)$; $d_{i j}$ is the shortest traffic distance between port $i$ and road $j$ (roads of different levels), and the road types include railway (train station), express way, trunk road and airport; and $\sigma_{j}$ is the weight value of the traffic trunk that has a positive correlation with road levels, and the higher the road level is, the greater the weight value. $L T_{i}{ }^{\prime}$ is the normalized influence of traffic trunk of 
port $i$, while $L T_{\max }$ and $L T_{\min }$ are the maximum and minimum values of the influence of traffic trunk of all ports.

(3) Road network density in hinterland

Hinterland traffic network density is used to reflect the accessibility of hinterland traffic and its support to the development of a port. Traffic roads include railway, expressway, and ordinary road. The port cargo collection and distribution methods are mainly railway transportation and trunk road transportation. Taking into account the capacity differences of transportation methods, different types of road networks are weighted and accumulated, The assessment model of road network density in hinterland is:

$$
\begin{gathered}
L D_{i}=\sum_{j=1}^{n} \sigma_{j}\left(L_{j} / A_{i}\right) \\
L D_{i}^{\prime}=\left(L D_{i}-L D_{\text {min }}\right) /\left(L D_{\text {max }}-L D_{\text {min }}\right)
\end{gathered}
$$

where, $L D_{i}$ is the hinterland road network density of port $i ; \sigma_{j}$ is the weight value of road; and $L_{j}$ is the total length of $j$-type roads in hinterland. $L D_{i}{ }^{\prime}$ is the normalized road network density in hinterland of port $i$, while $L D_{\max }$ and $L D_{\min }$ are the maximum and minimum values of road network density of all ports.

\subsubsection{Port location advantages}

The results of the port development potential assessment are obtained from the normalized processing results of the six indicators in the port development potential evaluation index system and their weights. The higher the location advantages of ports, the stronger the spatial connection between the port and the outside, and the greater the development potential; whereas, the weaker the spatial connection between the port and the outside, the smaller the development potential. The assessment model is:

$$
L A=\sum_{i=1}^{6} w_{i} Z_{i}
$$

where, $L A$ is the location advantage of Port $i$; $w_{i}$ is the weight value of the six indicators; $Z_{i}$ is the normalized value of the six indicators; $S F_{i}{ }^{\prime}, S P_{i}{ }^{\prime}, S N_{i}{ }^{\prime}, L C_{i}{ }^{\prime}, L T_{i}{ }^{\prime}$ and $L D_{i}{ }^{\prime}$ are respectively the normalized influence of strategic shipping pivot, the normalized competitiveness of port location potential, the normalized port network status, the normalized influence of city, the normalized influence of traffic trunk and the normalized road network density in hinterland of port $i$.

\section{Results and discussions}

\subsection{The calculations of port location advantages}

\subsubsection{The calculations of seaward indexes}

(1) The influence of strategic shipping pivot

A total of 44 strategic hubs, 7 strategic corridors and 3 strategic seas are identified worldwide (Wang et al., 2018b). The strategic hubs along the Maritime Silk Road include Singapore Port, Hong Kong Port, Shanghai Port, Shenzhen Port, Busan Port, Qingdao Port and Tokyo Port, the strategic corridors include the Strait of Malacca, the Strait of Hormuz, the Strait of Mandab, the Suez Canal, the Strait of Gibraltar, etc.; the strategic seas are 
Mediterranean Sea and Southeast Asia-Pacific Ocean, as shown in Figure 5. Those in the position of strategic pivot are valued 0 ; those close to strategic pivot are valued 0.5 ; and those away from strategic pivot are valued 1 , about $1 / 3$ of the research ports are located at the strategic pivot, and $1 / 4$ of the research ports are close to the strategic pivot. Considering that strategic hubs, strategic corridors and strategic seas all have significant influence on the evaluation of strategic shipping pivot, this paper utilizes equal-weight superposition to do the calculations. Thus, the distribution of the influence of strategic shipping pivot can be obtained according to formulas (1)-(2) (Figure 6).

As is shown in Figure 6, the influence of strategic shipping pivot generally distributes in a pattern of "high in the west, low in the east". The ports with high influence of strategic shipping pivot are mainly located in Strait of Gibraltar, Turkish Straights, the Suez Canal, the Strait of Mandab, Hormuz Strait and Strait of Malacca. These ports center on the ports with higher values, such as Algeciras Port (3.0) in Strait of Gibraltar, Port of Singapore (3.0) in Strait of Malacca, and Port of Istanbul (3.0) in Turkish Straits, etc. and their values decline from the centers. These high-valued ports guard strategic hubs, corridors and seas and enjoy remarkable geographic advantages. Whereas the ports with low influence of strategic shipping pivot are mainly located in the northeastern part of Europe, the northern coasts of Africa, China-Japan region and the northern part of Southeast Asia. Such ports are far away from strategic passages, thus having less geographic advantages.

(2) The competitiveness of port location potential

The scale of a port reflects the attributes of the port itself. The larger the scale of the port, the greater the opportunity for development. Therefore, this paper assigns $\{\mathrm{L}, \mathrm{M}, \mathrm{S}, \mathrm{V}\}$ to $\{1.5,1$, $0.5,0\}$, respectively, the distribution of the competitiveness of port location potential can be obtained according to formulas (3)-(4) (Figure 7).

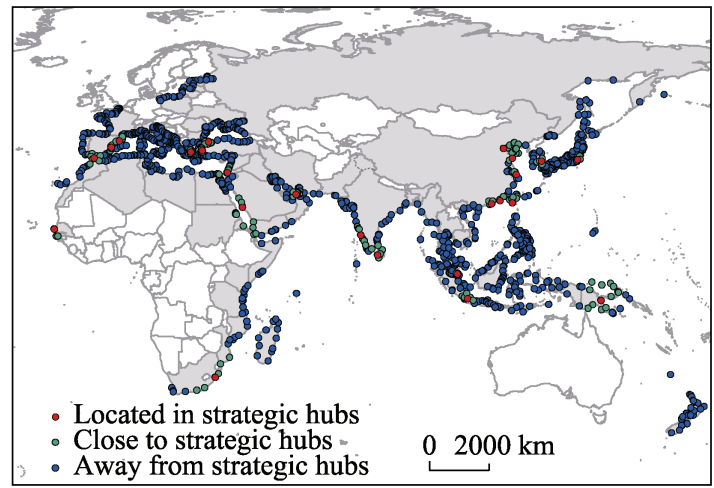

(b) Strategic corridor

(c) Strategic sea

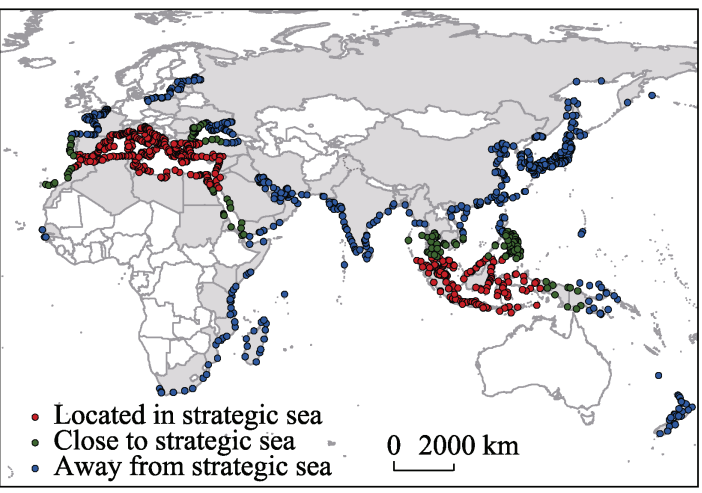

Figure 5 Space distribution of strategic shipping pivot (a) Strategic hub

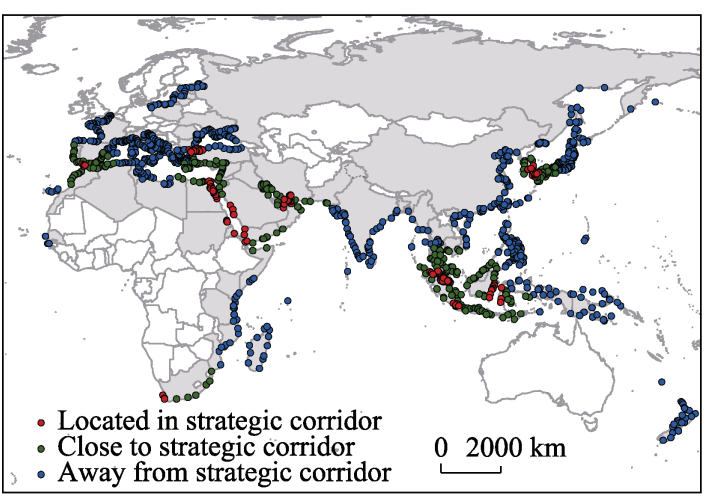


In Figure 7, the competitiveness of port location potential shows a declining trend from the north to the south. So, the regional features are obvious and the differences in the competitiveness of location potential among the ports are relatively wide. It can be seen that China, Japan and European countries in northern Mediterranean region have a relatively stronger competitiveness, in which Port of Hong Kong, Shanghai Port, Qingdao Port and Tianjin Port in China take the leading position because the strong economies, the complete infrastructures and the good services in the hinterlands of these ports can basically satisfy the supply needs of the vessels passing by, thus having a stronger competitiveness for sources of goods from the sea. However, African regions have the weakest competitiveness for sources of goods due to the backward economies and the delay in the development of shipping industry.

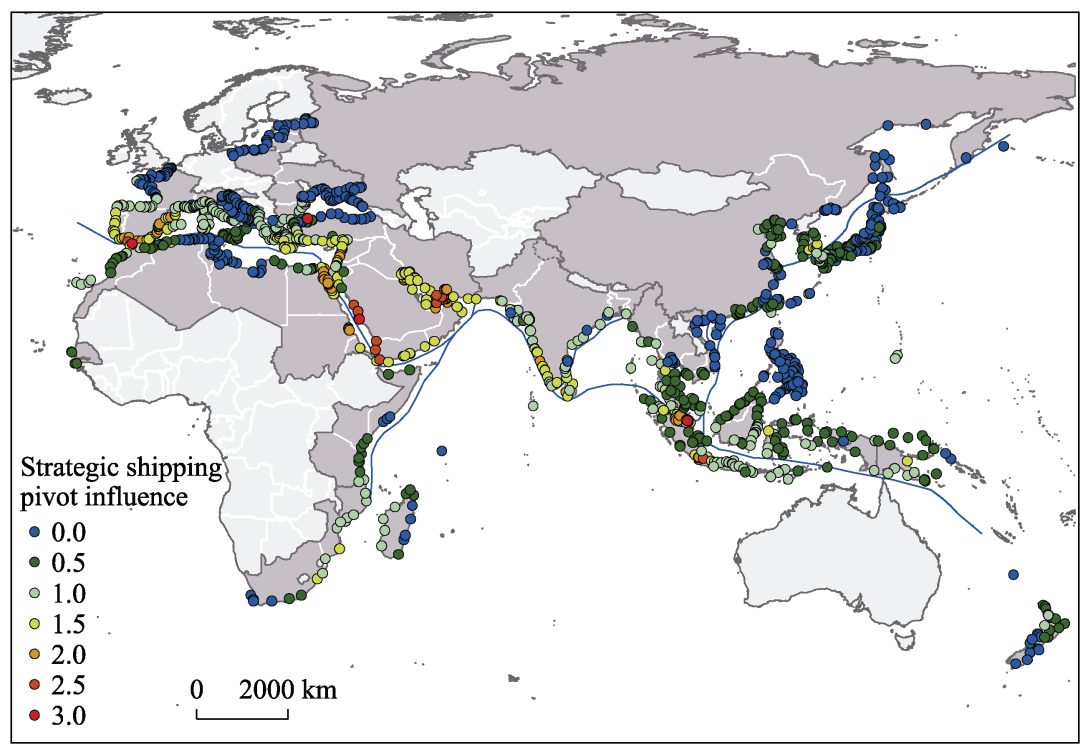

Figure 6 The influence of strategic shipping pivot in maritime transport

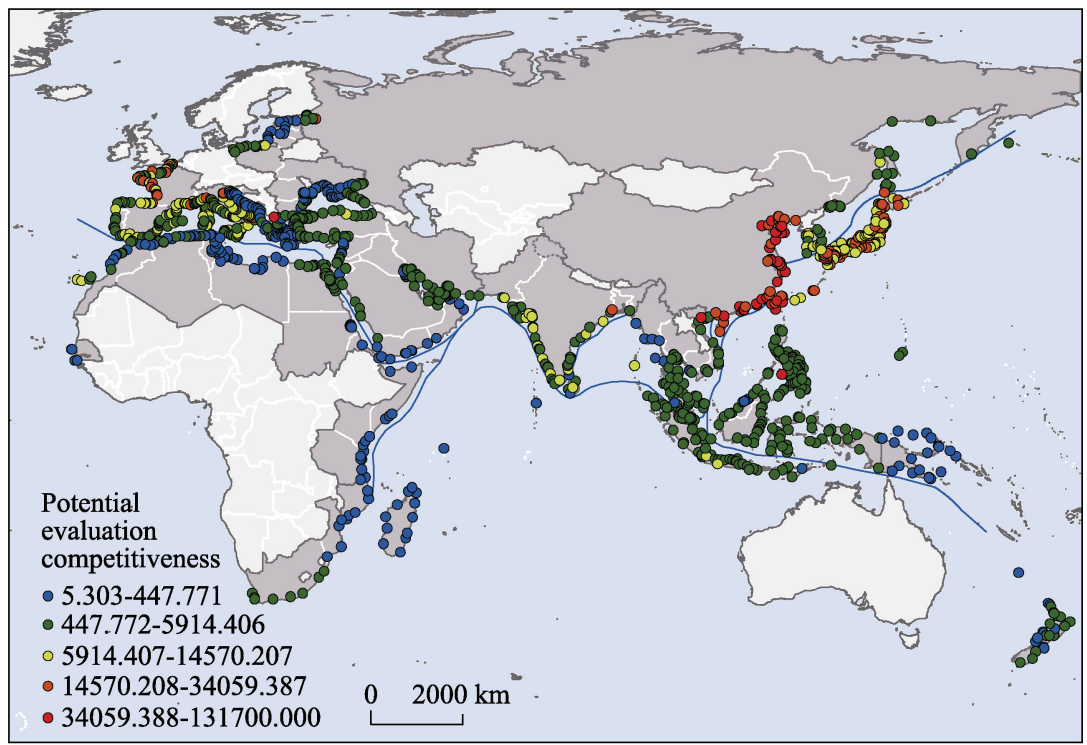

Figure 7 The competitiveness of location potential in maritime transport 
(3) Port network status

Weight values are given to the three assessment indexes of network status: node degree 0.225 , node betweenness 0.495 and node tightness 0.250 (Peng et al., 2018b). Based on the adjacency matrix that indicates the connection frequency between nodes, this paper forms a weighted undirected graph revealing the shipping network topology among ports (Figure 8). The distribution of port network status can be obtained according to formulas (5)-(9) (Figure 9).

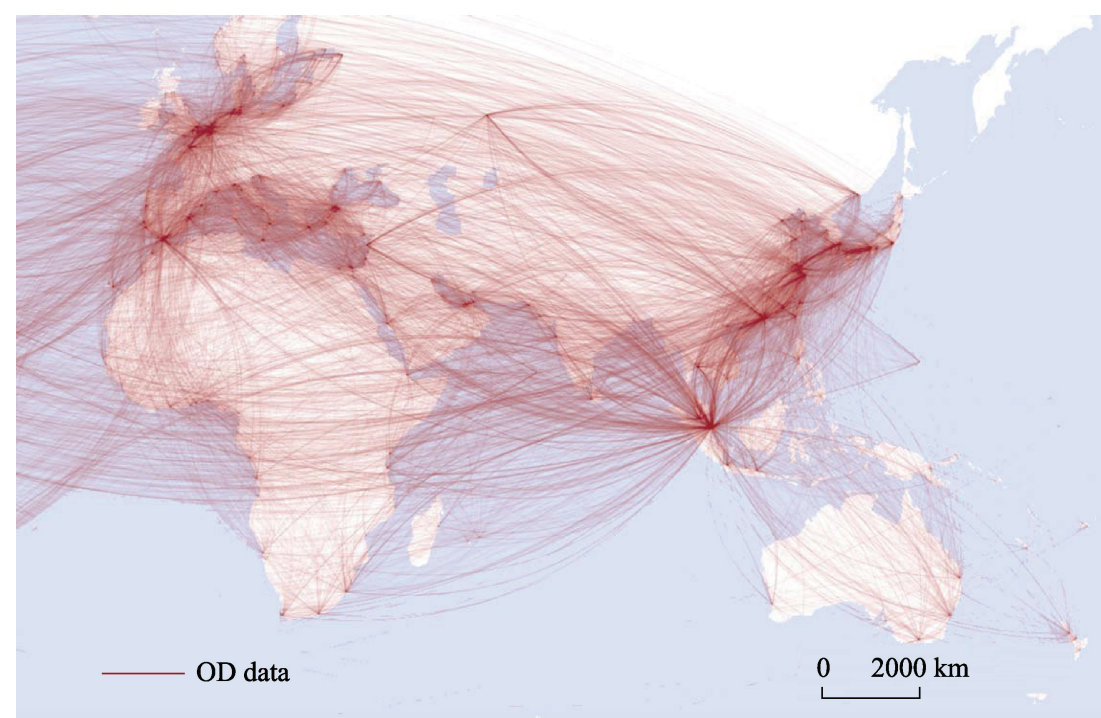

Figure 8 Structure of shipping network

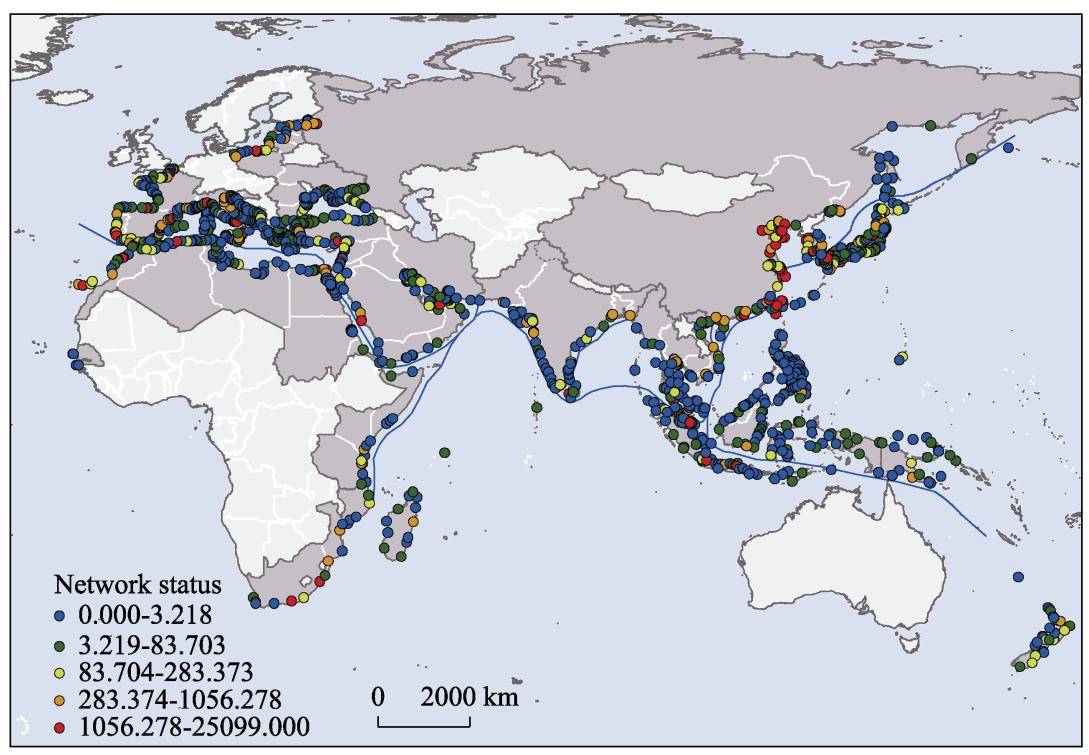

Figure 9 The importance of the network status in maritime transport

Figure 8 shows a quite unbalanced distribution of the annual cargo transportation frequencies in different regions. Regions in East Asia, Southeast Asia and Europe have the highest frequency, so they possess a relatively higher status and are more important in ship- 
ping network. In these regions, the trade between Port of Hong Kong and Shekou Port has the highest frequency, up to 3,184 times, followed by Port of Singapore and Port Kelang in Southeast Asian region, Port of Valencia and Port of Barcelona in European region; whereas the rest of the regions have relatively lower frequencies.

In Figure 9, the ports with high network status are mainly located in strategic passages and China-Japan region, so these ports have greater location advantages, wider range of radiation and better accessibility. For example, Port of Singapore lies in Strait of Malacca; it connects Pacific Ocean with Indian Ocean, and it is a way that East Asian countries have to pass to import strategic resources. Algeciras Port, lying in Strait of Gibraltar, links Mediterranean Sea with Atlantic Ocean. Port of Dubai lies in Hormuz Strait; it is an important corridor for the communication between the east and the west, but is also an important passage to Persian Gulf region and countries in Central Asia, South Africa and Eastern Europe.

\subsubsection{The calculations of landward indexes}

(1) The influence of city

The shortest distance between 1282 ports and the national capital, the first-level administrative center, the second-level administrative center was processed through ArcGIS. On the basis of the studies on economic and social statistics and other literatures ( $\mathrm{Xu}$ and Wang, 2009; Zhao et al., 2017), weight values are assigned to the parameters in the influence of city (Table 3 ). The distribution of the influence of city can be obtained according to formulas (10)-(11) (Figure 10).

Table 3 Calculation parameter of the influence of city

\begin{tabular}{lccc}
\hline \multicolumn{1}{c}{ Respects } & Range of influence $(\mathrm{km})$ & Attenuation coefficient & Weight \\
\hline Capital & 400 & $-1 / 10000$ & 40 \\
First-level administrative center & 100 & $-2 / 10000$ & 20 \\
Second-level administrative center & 50 & $-3 / 10000$ & 15 \\
\hline
\end{tabular}

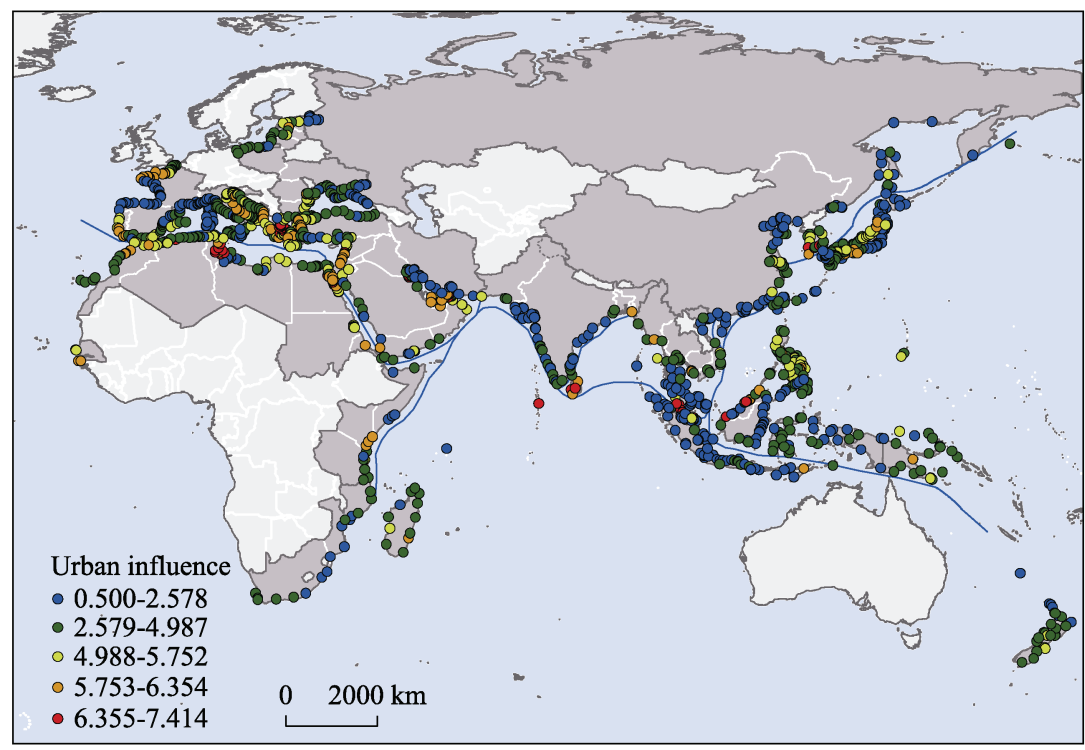

Figure 10 The influence of city in harbor hinterland 
As can be seen in Figure 10, the overall distribution of the influence of city is relatively scattered. Except a certain degree of high-value clusters along the Mediterranean coastlines, no remarkable regional characteristics exist in other regions. Generally, countries with high economic levels usually have higher levels of influence of city. Although some countries, such as Russia, China and India, have high economic levels, the long distances between major cities and the research ports (owing to the vast territories) lead to a relatively low degree of influence of city. On the other hand, some capital commercial ports, such as Port Mari in Maldives, Kuwait City Port in Kuwait and Port of Wellington in New Zealand, are close to the main cities, so the reductions in transportation distances reinforce the cities' support to the ports.

(2) The influence of traffic trunk

The influence of traffic trunk reveals the differences in traffic statuses in different regions through different levels of traffic facilities. The national vector data was downloaded through OpenStreeMap, and the shortest distance between 1282 ports and railway stations, highways, trunks, airports was processed through ArcGIS. In the light of distance-decay regularity and the features of various ways of transportation, weight values of the assessment indexes are determined (Zhou et al., 2012; Cui et al., 2019) (Table 4). The distribution of the influence of traffic trunk can be obtained according to formulas (12)-(13) (Figure 11).

Table 4 Calculation parameter of traffic trunk influence

\begin{tabular}{lccc}
\hline \multicolumn{1}{c}{ Respects } & Range of influence $(\mathrm{km})$ & Attenuation coefficient & Weight \\
\hline Railway (Railway Station) & 60 & $-1 / 30$ & 2 \\
Highway & 45 & $-1 / 30$ & 1.5 \\
Trunk & 15 & $-1 / 15$ & 1 \\
Airport & 10 & $-1 / 10$ & 1 \\
\hline
\end{tabular}

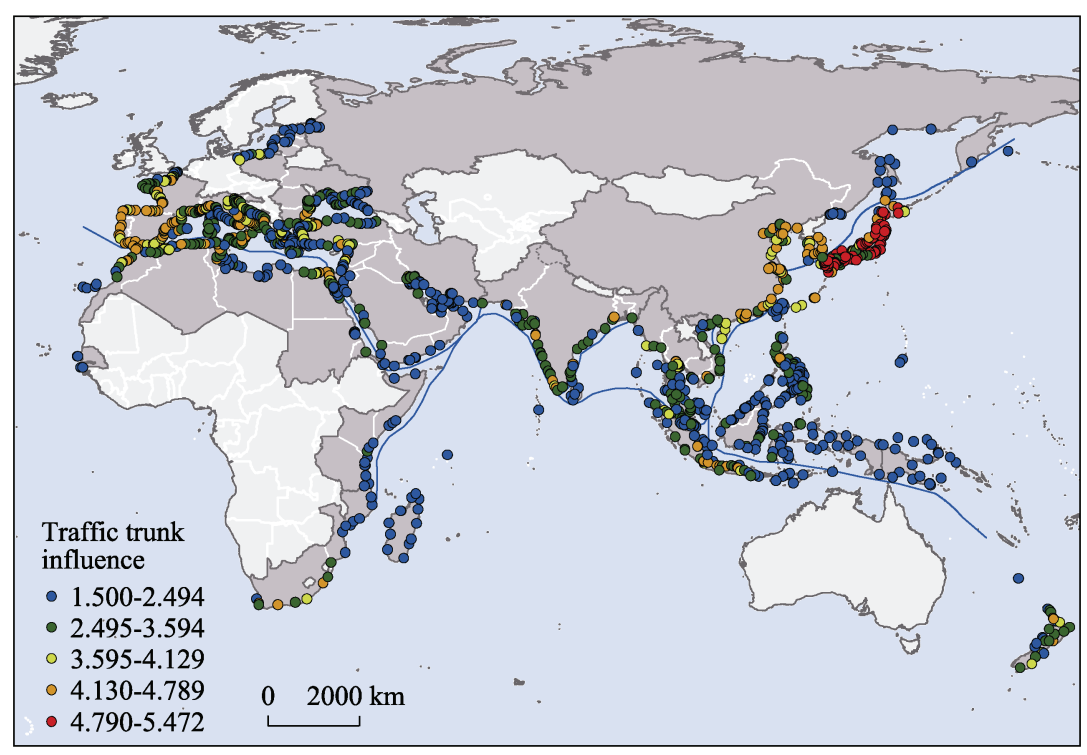

Figure 11 The influence of traffic trunk in harbor hinterland 
In Figure 11, coastal areas in Japan have remarkably higher traffic trunk influence than other regions, thus having the best support to the development of ports in this region; ports in China and Mediterranean coastal areas have relatively lower traffic trunk influence, while ports in west coast of Indian Ocean and eastern Southeast Asia have the lowest traffic trunk influence. According to statistics, countries with insufficient high-level traffic trunks have low traffic trunk influence. For example, railroads have not been built in 11 countries, i.e. Libya, Lebanon, Somalia, Yemen, Oman, Kuwait, Maldives, Timor-Leste, Brunei, Papua New Guinea and Eritrea; while expressways have not been built in 10 countries, i.e. Somalia, Yemen, Maldives, Timor-Leste, Papua New Guinea, Eritrea, Sudan, Iraq, Bengal and Cambodia. Therefore, traffic trunks in these countries have relatively weak support to the development of their ports. Nevertheless, in western developed countries ports are quite developed and have complete traffic facilities, so these ports have a relatively higher traffic trunk influence.

(3) Road network density in hinterland

Through the China Belt and Road Network and the US Central Intelligence Agency, the land area of 63 countries and the mileage of railways, expressways and normal roads were collected, based on the transportation capacities of railways, expressways and normal roads, weight values are assigned to the following indexes: railway 0.4 , expressway 0.3 , and normal road 0.2 (Mou et al., 2018a). The distribution of hinterland road network density can be obtained according to formulas (14)-(15) (Figure 12).

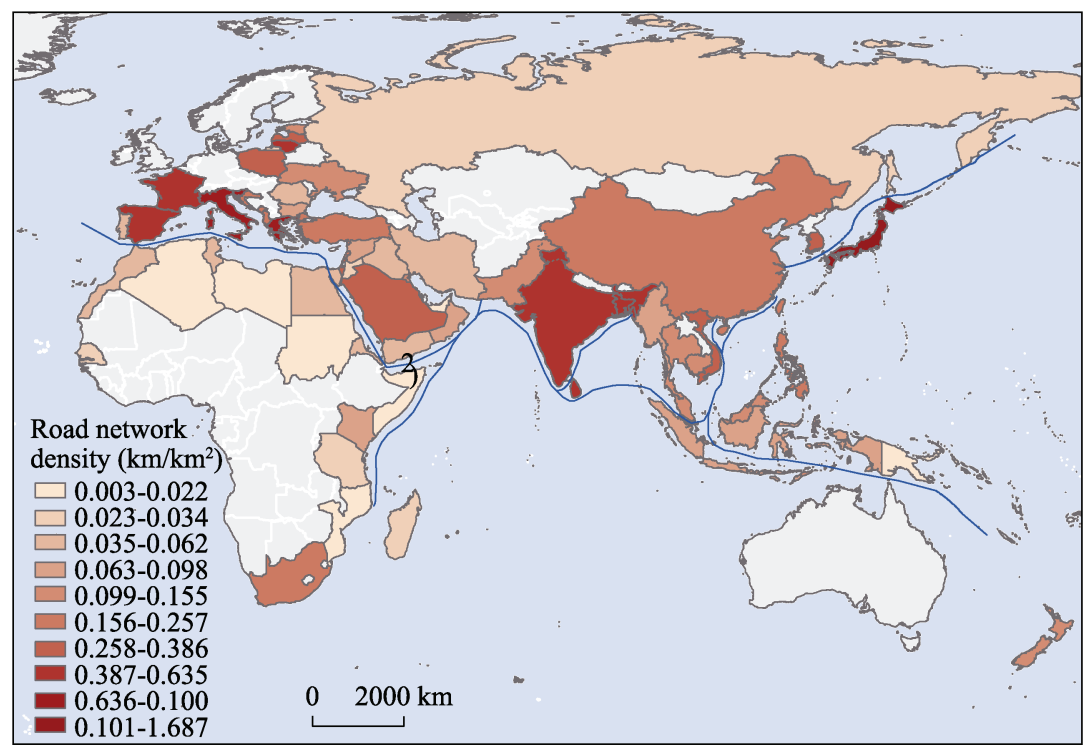

Figure 12 Road network density in harbor hinterland

In Figure 12, 11 countries have hinterland road network densities between $0.387-1.687$ $\mathrm{km} / \mathrm{km}^{2}$, mainly in Singapore, Japan and Southern European countries, in which Singapore $\left(1.687 \mathrm{~km} / \mathrm{km}^{2}\right)$ and Japan $\left(1.155 \mathrm{~km} / \mathrm{km}^{2}\right)$ have the highest density, and this indicates that a small number $(17.46 \%)$ of the ports have high-level hinterland road network densities. Thirty countries have densities between $0.063-0.386 \mathrm{~km} / \mathrm{km}^{2}$, mainly in China, New Zea- 
land, South Africa, Saudi Arabia, Oman, Pakistan, Southeast Asian and Eastern European countries, and this shows that about half (47.62\%) of the ports have intermediate-level hinterland road network densities. Twenty-two countries have densities between 0.003-0.062 $\mathrm{km} / \mathrm{km}^{2}$, mainly in Russia, Papua New Guinea, African and West Asian countries, which reveals that a minority (34.92\%) of ports have low-level hinterland road network densities. According to statistics, the study also has the following findings. Firstly, 11 countries (about $17.46 \%$ ) have no railway, 10 countries (about $15.87 \%$ ) have no expressway, mainly some countries with poor economy, turbulent national situation, restricted terrain or small area. Secondly, 20 countries (about 31.75\%) have total railway lengths of over $5000 \mathrm{~km}$, mainly the countries in Asia and Europe, only 9 countries (about 14.29\%) have total expressway lengths of over $5000 \mathrm{~km}$, mainly the countries of East Asia, South Asia and Europe.

\subsubsection{The calculations of port location advantages}

After calculation according to the Formulas (1)-(5) in the Appendix, the weight scores of the influence of strategic shipping pivot, the competitiveness of location potential, port network status, the influence of city, the influence of traffic trunk and road network density in hinterland are shown in Table 5. Then this paper obtains the location advantages of 1259 ports in 63 countries along the Maritime Silk Road by Formula (16), and the location advantages are divided into 5 levels according to Jenks (Figure 13).

Table 5 The weight of evaluation index

\begin{tabular}{|c|c|c|c|c|c|}
\hline \multirow{4}{*}{$\begin{array}{l}\text { Seaward } \\
\text { index }\end{array}$} & Indicators & Weights & \multirow{4}{*}{$\begin{array}{l}\text { Landward } \\
\text { index }\end{array}$} & Indicators & Weights \\
\hline & $\begin{array}{l}\text { The influence of } \\
\text { strategic shipping pivot }\end{array}$ & 0.164 & & The influence of city & 0.156 \\
\hline & $\begin{array}{l}\text { The competitiveness of } \\
\text { port location potential }\end{array}$ & 0.196 & & $\begin{array}{l}\text { The influence of traffic } \\
\text { trunk }\end{array}$ & 0.134 \\
\hline & Port network status & 0.185 & & $\begin{array}{l}\text { Road network density in } \\
\text { hinterland }\end{array}$ & 0.165 \\
\hline
\end{tabular}

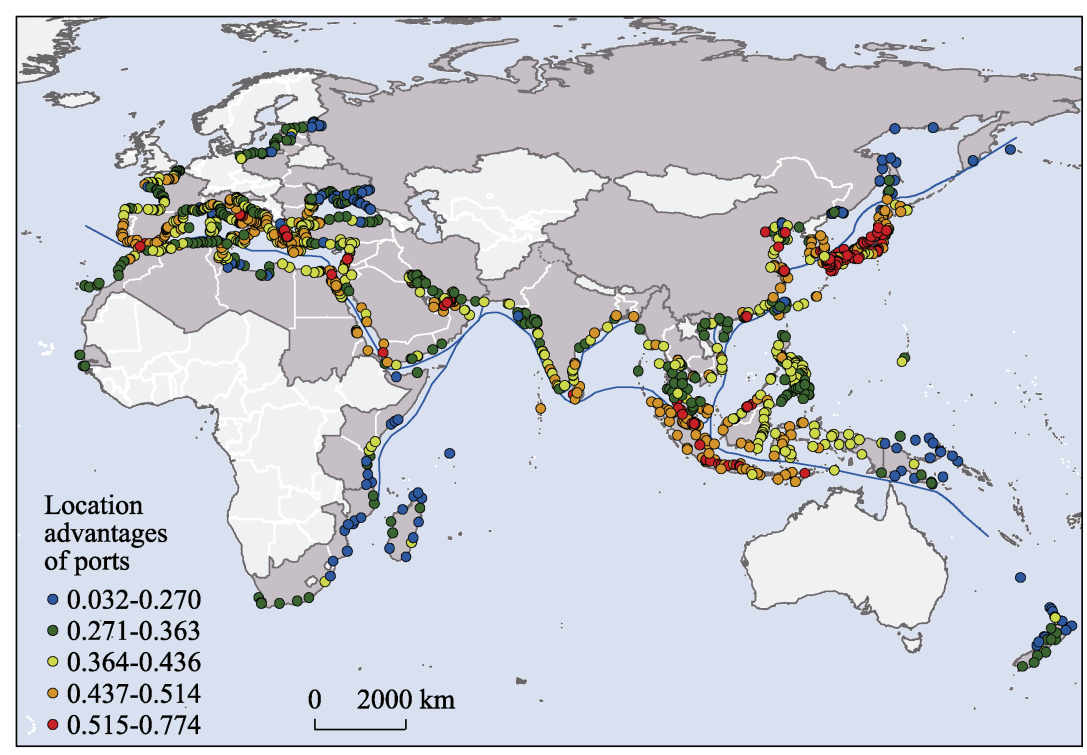

Figure 13 Location advantages of ports along the Maritime Silk Road 


\subsection{Spatial pattern analysis of location advantages of the ports}

The location advantages of the ports show a "high-low-high" distribution pattern from the west to the east. Such a distribution pattern centers on ports in China-Japan region, Strait of Malacca and northern Mediterranean European countries and displays a declining trend from the center. The main features of the spatial pattern are as follows:

(1) The number of the ports with different levels of location advantages shows a positively skewed distribution, which means most ports along the Maritime Silk Road have relatively high location advantages (Figure 14). Among the first-level ports, 8 abnormal values are found, i.e. Port of Singapore (0.774), Port of Pulau Bukom (0.761), Port of Jurong Island (0.7569), Port of Serangoon (0.734), Port of Pulau Sebarok (0.733) in Singapore and Port of Hong Kong, Shanghai Port in China as well as Port Klang in Malaysia. These abnormal values prove that the 8 ports possess outstanding location advantages. While among the fifth-level ports, 3 abnormal values are found, i.e. Port of Bukhta Nagayeva (0.099) in Russia and Port of Whangaroa (0.079), Port of Kingston (0.032) in New Zealand, which indicates that these 3 ports have remarkable location disadvantages.
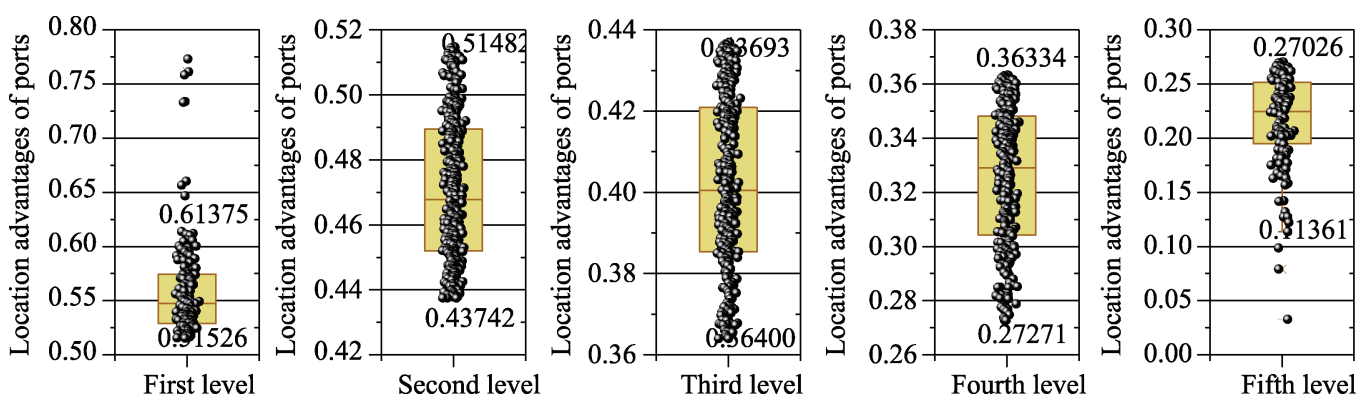

Figure 14 Level distribution box plot of location advantages of ports

(2) Ports with higher location advantages are mainly located in Strait of Malacca, the United Arab Emirates, northern Mediterranean coastal region and China-Japan region. Two reasons are found for this. First, most of these ports are located in important strategic passages, such as Port of Singapore (0.774) in Strait of Malacca, Algeciras Port (0.598) in Strait of Gibraltar and Port of Dubai in Hormuz Strait; such important strategic passages are unavoidable for global ship transportations. Second, these ports are mostly in developed countries with high economic levels, such as Port of Shingu (0.614) in Japan, Port of Piraeus (0.588) in Greece and Port of Genoa (0.530) in Italy, etc. In addition, with the rapid development of economy, China has already become one of the top maritime countries in the world, for it not only takes a large share in the world's total throughput but also possesses many top-rank ports in the world, such as Zhoushan Port, Shanghai Port and Port of Hong Kong. As is shown in Table 6, the top 10 ports with high location advantages are mainly in Singapore, China, Malaysia and Japan. This shows a growing economic influence from Asia-Pacific region and indicates the shift of the world shipping center from the west to the east.

(3) Ports with lower location advantages are mainly located in African coastal areas, 
Oceania, Northeast Europe and Russia. The reasons are listed below. On one hand, the historical factors within a long period slowed down economic growths. For example, Africa has many great natural harbors but small throughputs because of the underdeveloped economies and the old port facilities. On the other hand, wars stopped many harbors from fast development, such as Port of Al Ladhiqiyah (0.360) in Syria, Port of Khawr Al Amaya (0.272) in Iraq in West Asia and Port of Al Burayqah (0.221) in Libya, Port of Kismaayo (0.189) in Somalia in Africa. Also, some ports are far away from strategic passages and have poor accessibilities, thus having fewer opportunities for development. For instance, New Zealand is relatively far away from the Belt and Road countries, but its trade is highly dependent on the rest of the world, especially China. As can be seen from Table 7, the last 10 ports with low location advantages are mainly in New Zealand and Russia. Although Russia has the largest land area in the world, insufficient investments and harsh climate cause unbalanced development of road network. As a result, the low city road network density, together with the short navigation period caused by the long ice period for most of its harbors, brings Russia neither seaward nor landward location advantages.

Table 6 Top 10 ports in location advantages

\begin{tabular}{cllrrrrrrr}
\hline \multirow{2}{*}{ Rank } & \multirow{2}{*}{ Port } & \multirow{2}{*}{ Country } & $\begin{array}{c}\text { Rank in } \\
\text { SF }\end{array}$ & $\begin{array}{r}\text { Rank in } \\
\text { SP }\end{array}$ & $\begin{array}{r}\text { Rank in } \\
\text { SN }\end{array}$ & $\begin{array}{c}\text { Rank in } \\
\text { LC }\end{array}$ & $\begin{array}{c}\text { Rank in } \\
\text { LT }\end{array}$ & $\begin{array}{c}\text { Rank in } \\
\text { LD }\end{array}$ & Score \\
\hline 1 & Singapore & Singapore & 1 & 25 & 7 & 5 & 133 & 1 & 0.774 \\
2 & Pulau Bukom & Singapore & 2 & 75 & 9 & 6 & 134 & 2 & 0.761 \\
3 & Jurong Island & Singapore & 3 & 26 & 11 & 2 & 136 & 3 & 0.759 \\
4 & Serangoon & Singapore & 4 & 86 & 94 & 4 & 132 & 4 & 0.734 \\
5 & Pulau Sebarok & Singapore & 5 & 83 & 123 & 3 & 135 & 5 & 0.733 \\
6 & Hong Kong & China & 189 & 2 & 1 & 48 & 57 & 36 & 0.660 \\
7 & Shanghai & China & 190 & 1 & 3 & 47 & 18 & 17 & 0.657 \\
8 & Port Klang & Malaysia & 6 & 127 & 8 & 54 & 279 & 228 & 0.647 \\
9 & Shingu & Japan & 78 & 44 & 295 & 67 & 1 & 6 & 0.614 \\
10 & Hannan Ko & Japan & 79 & 45 & 336 & 74 & 2 & 7 & 0.612 \\
\hline
\end{tabular}

Table 7 Last 10 ports in location advantages

\begin{tabular}{lllccccccc}
\hline \multirow{2}{*}{ Rank } & \multirow{2}{*}{ Port } & \multirow{2}{*}{ Country } & $\begin{array}{c}\text { Rank in } \\
\text { SF }\end{array}$ & $\begin{array}{c}\text { Rank in } \\
\text { SP }\end{array}$ & $\begin{array}{c}\text { Rank in } \\
\text { SN }\end{array}$ & $\begin{array}{c}\text { Rank in } \\
\text { LC }\end{array}$ & $\begin{array}{c}\text { Rank in } \\
\text { LT }\end{array}$ & $\begin{array}{c}\text { Rank in } \\
\text { LD }\end{array}$ & Score \\
\hline 1250 & Petropavlovsk & Russia & 1259 & 921 & 1236 & 1257 & 1258 & 1121 & 0.157 \\
1251 & Nikol Skoye & Russia & 1258 & 920 & 1237 & 1256 & 1259 & 1122 & 0.142 \\
1252 & De Kastri & Russia & 1201 & 918 & 1190 & 1236 & 1249 & 1123 & 0.132 \\
1253 & Nikolayevsk & Russia & 1200 & 911 & 1196 & 1237 & 1250 & 1124 & 0.127 \\
1254 & Okha & Russia & 1193 & 912 & 1197 & 1238 & 1251 & 1125 & 0.127 \\
1255 & Vitaz Marine Ter- & Russia & 1194 & 919 & 1203 & 1255 & 1252 & 1126 & 0.122 \\
1256 & Okhal & Russia & 1256 & 910 & 1214 & 1258 & 1257 & 1127 & 0.114 \\
1257 & Bukhta Nagayeva & Russia & 1257 & 916 & 1234 & 1259 & 1258 & 1128 & 0.099 \\
1258 & Whangaroa & New Zealand & 907 & 1041 & 1239 & 1253 & 928 & 894 & 0.079 \\
1259 & Kingston & New Zealand & 1157 & 1042 & 1240 & 1254 & 1209 & 895 & 0.032 \\
\hline
\end{tabular}


The global spatial autocorrelation coefficient is 0.327 , which shows a certain spatial aggregation pattern on the location advantages of the ports along the Maritime Silk Road. In order to more accurately investigate the heterogeneity features of the location advantages, a further analysis is done on Anselin Local Moran I and the result is shown in Figure 15:

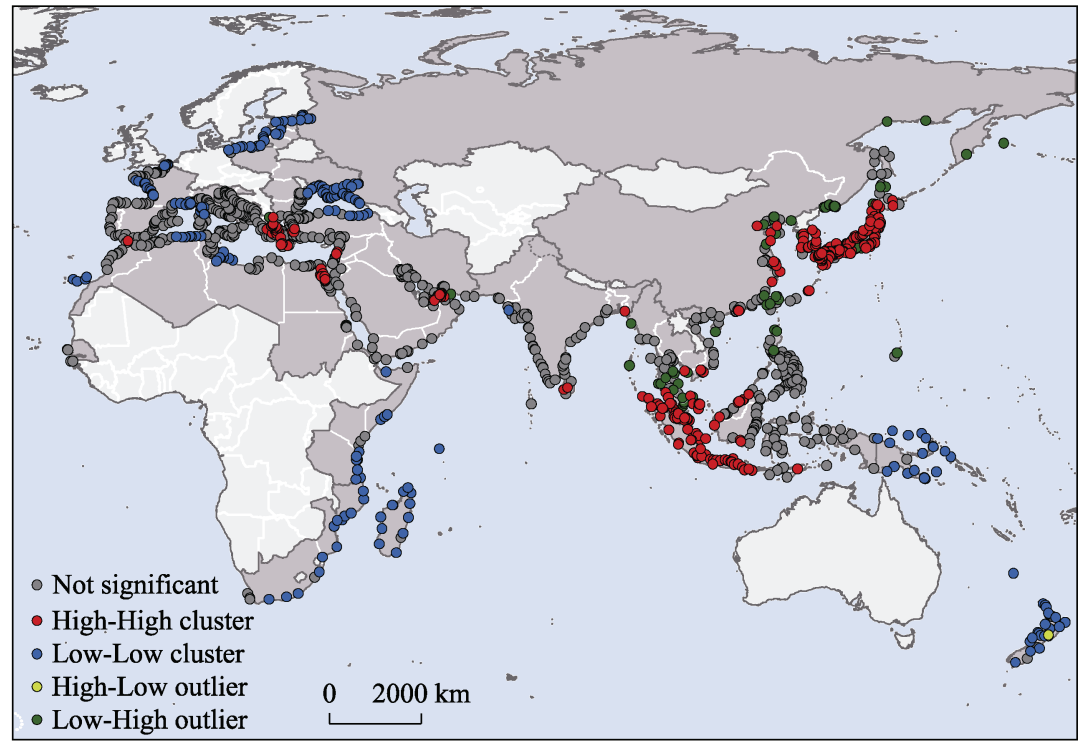

Figure 15 The high/low clustering of location advantages of ports

1) Ports in Strait of Malacca, Strait of Gibraltar, Turkish Straits, Suez Canal, Hormuz Strait, China-Japan region, Colombo Port in Sri Lanka and Chattogram Port in Bangladesh show a High-High Cluster feature. Among these ports, Colombo Port (0.521) is a hub port in South Asia for transshipment, but is also an important intermediate port for international shipping lines in Eurasian, Pacific and Indian Ocean regions. Its cargo transportation growth rate ranked the 1 st in the world in 2014, the year when it was built; and it became a world-level port with a container throughput ranking the 27th in 2016. In addition, Chattogram Port (0.489), lying in northeastern part of the Bay of Bengal, is the industrial base and traffic hub of Bangladesh. It has a superior geographic location and a natural harbor with a lot of docks. Consequently, frequent foreign trades strengthened its location advantages. 2) Ports along African coastlines, European coastlines, in Oceania region and Okha Port in India show a Low-Low Cluster feature. Okha Port (0.356) lies in southwest Gujarat in India. Although it has natural location disadvantages, such as backward construction and low handling capacity, it is supported by rapid economic development in Gujarat after the implementation of "Modinomics"; therefore, Okha Port has a great potential in location advantages. 3) Port of Wellington in New Zealand shows a High-Low Outlier feature because it is not only a capital commercial port but also a traffic hub between its two islands. Thus, it has remarkable advantages over other ports around. 4) Part of the ports in eastern Russian coastlines, China and Japan as well as the ports in Southeast Asia show a Low-High Outlier feature because the ports in these regions have experienced quite unbalanced developments 
and large-scale High-High Cluster ports exist at the same time. As a result, relatively new emerging ports have obvious location disadvantages due to relatively slow developments and weak conditions.

\subsection{Discussion}

The influence of each indicator on location advantages of ports is ranked as follows: the competitiveness of port location potential, port network status, road network density in hinterland, the influence of strategic shipping pivot, the influence of city and the influence of traffic trunk. It is shown that the significance of sea-oriented location conditions of ports is higher than that of land-oriented location conditions. That is to say, the improvement of the status of ports in the maritime network is stronger than relying on hinterland traffic and the support of cities. Therefore, all ports should optimize trade routes, increase the absorption of goods sources, and strengthen trade exchanges. It is important to explore their own advantages, match the needs of the development situation, and accurately cut into the receiving port. So how to improve the sea-direction location conditions of the port? From the perspective of basic indicators, in order to improve the competitiveness of port location potential indicators, it is fundamentally necessary to enhance the economic conditions of the hinterland and its own throughput capacity, and these two factors also have the greatest impact on location advantages of ports; from the perspective of port network status, the node betweenness weight is the highest, indicating that compared with the number of routes and short route distance, the core transit status in the maritime network has a stronger role and influence. For example, Singapore Port, a global hub port, guarding the Strait of Malacca, relies to a large extent on its irreplaceable transit status. Therefore, it is recommended that ports located in transit locations need to fully develop and give full play to their position advantages.

In addition, in the indicator of the influence of strategic shipping pivot, if the port wants to improve in aspects of the strategic hub, strategic corridor and strategic sea, it mainly depends on whether it has a significant geographic advantage. However, the shipping pattern is dynamically changing and evolving, and it is still possible for neighboring ports to change their position advantages through correct strategic cooperation. In addition, the spatial distribution of socio-economic activities and communications determine the strategic value of these points, business organization, technical progress, and geopolitical disputes all function to strengthen the strategic mechanisms and the mutagenicity of strategic shipping pivots (Wang et al., 2018). In terms of land location conditions, the road network density in hinterland index is the most important, for countries with different land areas and diverse transportation methods, further comprehensive consideration of other transportation methods such as pipeline transportation, water transportation, air transportation, and the spatio-temporal changes of road network density will make the results more meaningful. For example, Russia has a large land area, and most of its oil and gas trade with China is carried out through pipelines which is taken as an issue worthy of further investigation.

An imbalance exists in the spatial pattern of location advantages of ports along the Maritime Silk Road. Generally, 8 ports are taking the leading position, i.e. Port of Singapore, Port of Pulau Bukom, Port of Jurong Island, Port of Serangoon, Port of Pulau Sebarok in Singa- 
pore, Port of Hong Kong and Shanghai Port in China, and Port Klang in Malaysia. Among these ports, Port of Singapore and Port of Hong Kong have absolute location advantages and thus have become the transshipment hub ports for neighboring countries and regions. The development of transshipment hub ports mainly relies on the distribution of cargo vessels from neighboring feeder ports. Thus, based on the findings on location advantages and seaward indexes, this paper conjectures that Port of Jurong Island in Singapore will become another transshipment hub port. The reasons are as follows. First, the location advantages and seaward location advantages of this port are both in the leading position. Second, Port of Jurong Island, as the biggest feeder port in Asia, not only has 23 docks for vessels with a 16-meter-draft but also has ultramodern warehouse facilities, which greatly improves transshipment efficiency. Also, some other ports will become hinterland-induced hub ports for their location advantages, complete and efficient inland transportation networks and strong hinterland economies. So, based on the findings on location advantages and landward indexes, this paper further conjectures that Port of Shingu, Port of Hannan Ko in Japan and Shanghai Port in China will become international hinterland-induced hub ports in the future. Considering the fierce competition among ports in the 21 st century, investing in some key ports is the strategy practiced by every country. Thus, conjectures in this study can provide scientific judgments, based on the exact situations of each country, for determining the key ports to be invested in.

However, it needs pointing out that the assessment indexes in this paper have certain limitations, for they do not give sufficient consideration to policies, safety, water pollution and other factors. Also, future efforts are needed to further study the utilization of location advantages to avoid location disadvantages and, in return, to make a breakthrough for the construction, development of ports and the cooperation among them.

\section{Conclusions}

Based on the influence of strategic shipping pivot, the location advantages, network status, the influence of city, the influence of traffic trunk and road network density in hinterland, this paper does a quantitative analysis on the location advantages and spatial patterns of the ports along the Maritime Silk Road. And the results are as follows:

First, the location advantages of ports along the Maritime Silk Road show a "highlow-high" spatial pattern from the west to the east, and the location advantages of most ports are on a medium level or a little higher level. Ports with high location advantages are mainly in Strait of Malacca, the United Arab Emirates, northern Mediterranean coastal region and China-Japan region. Among these ports, the top 10 are mainly in Singapore, China, Malaysia and Japan, which shows a growing global influence from Asia-Pacific region and indicates the shift of the world shipping center to the east. In addition, ports with lower location advantages are mainly located in African coastal areas, Oceania, Northeast Europe and Russia, among which the last 10 ports are mainly in New Zealand and Russia. Besides, Port of Singapore still ranks the first in location advantages; however, Port of Pulau Bukom, Port of Jurong Island, Port of Serangoon, Port of Pulau Sebarok in Singapore and Port of Hong Kong, Shanghai Port in China are competing for the second place. 
Second, judging from a single index, this paper has the following conclusions. 1) Ports other than important shipping passages have a generally low level of influence of strategic shipping pivot. 2) China, Japan and European countries in northern Mediterranean region have a relatively stronger competitiveness of location potential. However, the African countries and regions are affected by the limited scale of trade and limited levels of economic development, and all ports are at the medium-lower level, and the supply of goods is less competitive. 3) East Asian, Southeast Asian and European regions have relatively higher statuses in shipping network. 4) The distribution of the influence of city is mainly influenced by the development of a country and its land area, and the influence of city is in proportion to the economic level. 5) Ports in Japan have the highest influence of traffic trunk, followed by ports in China and ports along the Mediterranean coastlines, whereas ports in the west coastlines of Indian Ocean and the eastern part of Southeast Asia have the lowest influence of traffic trunk. 6) Except in developed countries and some developing countries with high levels of economy, ports in other countries have relatively lower hinterland road network densities.

Third, from the point of view of the importance of indicators, the ranking of the six indicators on the influence of location advantages of ports is as follows: the competitiveness of port location potential, port network status, road network density in hinterland, the influence of strategic shipping pivot, the influence of city and the influence of traffic trunk. Moreover, the sea-oriented location advantages have a higher influence than the land-oriented location advantages. Among them, the competitiveness of port location potential determines the sea-oriented location advantages of the port. Road network density in hinterland is the core indicator that determines the advantage of the port's land orientation.

\section{Appendix}

The weight of the evaluation indicators is determined by Entropy, and the specific processes are as follows:

(1) Data normalization. It aims to unify the units of each indicator, and makes the data dimensionless processing of each indicator so that its values are between $[0,1]$. Among them, the larger the index value, the better type of benefit indicators (Formula (17)), while the smaller the index value, the better type of cost indicators (Formula (18)). $y_{i j}$ is the standard value of the $i$-th object based on the $j$-th index.

$$
\begin{gathered}
X=\left(x_{i j}\right)_{m \times n} \quad i=1,2, \ldots, m ; j=1,2, \ldots, n \\
Y=\left(y_{i j}\right)_{m \times n} \quad i=1,2, \ldots, m ; j=1,2, \ldots, n \\
y_{i j}=\frac{x_{i j}-\min \left(x_{j}\right)}{\max \left(x_{j}\right)-\min \left(x_{j}\right)} \\
y_{i j}=\frac{\max \left(x_{j}\right)-x_{i j}}{\max \left(x_{j}\right)-\min \left(x_{j}\right)}
\end{gathered}
$$

(2) Indicator weight calculation. Calculate the proportion $p_{i j}$ of the $i$-th evaluation object under the $j$-th index (Equation (19)), the entropy value $E_{j}$ of the $j$-th indicator (For- 
mula (20)) and the entropy weight $W_{j}$ of the $j$-th indicator (Formula (21)), and $W_{j}$ is the entropy weight of the $j$-th indicator that we need.

$$
\begin{gathered}
p_{i j}=\frac{y_{i j}}{\sum_{i=1}^{m} y_{i j}} \\
E_{j}=-\frac{1}{\ln m} \sum_{i=1}^{m} p_{i j} \ln p_{i j} \\
W_{j}=\frac{1-E_{j}}{\sum_{j=1}^{n}\left(1-E_{j}\right)}
\end{gathered}
$$

\section{References}

An X P, Han Z L, Yang Y K, 2000. Research on the formation and evolution mechanism and development model of international container hub port. Geographical Research, 19(4): 383-390. (in Chinese)

Awasthi A, Chauhan S S, Goyal S K, 2011. A multi-criteria decision making approach for location planning for urban distribution centers under uncertainty. Mathematical \& Computer Modelling, 53(1): 98-109.

Bird J, 1965. The Major Seaports of the United Kingdom. London: Hutchinson.

Chen T, Wang K Y, Chen Y F, 2018. The influence and quantitative measure methods of administrative division adjustment on administrative region political: Taking Chongqing city as a case. Scientia Geographica Sinica, 38(5): 654-661. (in Chinese)

Cui X G, Fang C L, Wang Z B et al., 2019. Spatial relationship of high-speed transportation construction and land-use efficiency and its mechanism: Case study of Shandong Peninsula urban agglomeration. Journal of Geographical Sciences, 29(4): 549-562.

Dong J S, Fan B Q, Liu W W, 2006. Port location model and its growth mechanism. Journal of Systems \& Management, 15(3): 215-219. (in Chinese)

Ducruet C, Cuyala S, El Hosni A, 2018. Maritime networks as systems of cities: The long-term interdependencies between global shipping flows and urban development (1890-2010). Journal of Transport Geography, 66(1): $340-355$.

Ducruet C, Haule S, Ait-Mohand K et al., 2015. Maritime shifts in the world economy: Evidence from the Lloyd's List corpus, eighteenth to twenty-first centuries. In: Ducruet C (ed). Maritime Networks. Spatial Structures and Time Dynamics. London: Routledge Press, 134-160.

Greenwood R H, Hoyle B S, Hilling D, 1985. Seaport systems and spatial change: Technology, industry and development strategies. Geographical Journal, 151(1): 116.

Guo J K, Wang S B, Wang H et al., 2017. Comprehensive measure of the regional advantages of national scenic area. Economic Geography, 37(1): 187-195. (in Chinese)

Hall P, 1991. Waterfronts: a New Urban Frontier.

HKTDC, Belt and Road, 2017. Retrieved from http://beltandroad.hktdc.com/en/about-the-belt-androad-initiative/ about-the-belt-and-road-initiative.aspx.

Hoyle B, Pinder D, 1981. Cityport Industrialization and Regional Development: Spatial Analysis and Planning Strategies. Oxford: Pergamon Press.

Jiang B, Li J, Gong C, 2018. Maritime shipping and export trade on "Maritime Silk Road". The Asian Journal of Shipping and Logistics, 34(2): 83-90. 
Jiang J L, Lee L H, Chew E P et al., 2015. Port connectivity study: An analysis framework from a global container liner shipping network perspective. Transportation Research Part E: Logistics and Transportation Review, 73(1): 47-64.

Jin F J, Wang C J, Li X W, 2008. Discrimination method and application analysis of China's regional transportation advantages. Acta Geographica Sinica, 68(8): 787-798. (in Chinese)

Kavirathna C A, Kawasaki T, Hanaoka S, 2019. Intra-port coopetition under different combinations of terminal ownership. Transportation Research Part E: Logistics and Transportation Review, 128(1): 132-148.

Kojaku S, Xu M, Xia H et al., 2019. Multiscale core-periphery structure in a global liner shipping network. Scientific Reports, 9(1): 1-15.

Kosowska-Stamirowska Z, Ducruet C, Rai N, 2016. Evolving structure of the maritime trade network: Evidence from the Lloyd's Shipping Index (1890-2000). Journal of Shipping and Trade, 1(1): 1-10.

Li S, Wang Z, Zhong Z Q, 2012. The gravitational model of tourism space interaction and its application. Acta Geographica Sinica, 67(4): 526-544. (in Chinese)

Liu F, Andrienko G, Andrienko N et al., 2020. Citywide traffic analysis based on the combination of visual and analytic approaches. Journal of Geovisualization \& Spatial Analysis, 4(2): 15.

Liu Y, Sui Z, Kang C et al., 2014. Uncovering patterns of inter-urban trip and spatial interaction from social media check-in data. PLoS ONE, 9(1): e86026.

Lu F, Chen J, 2008. Location superiority and accessibility analysis on Wuhan metropolitan region. Progress in Geography, 27(4): 68-74. (in Chinese)

Ma Q Y, Ma J H, Zhang C, 2006. Research on transportation network evaluation based on network analysis and its relationship with regional economic development. Human Geography, 21(4): 113-116, 78. (in Chinese)

Mayer H M, 1978. Current trends in Great Lakes shipping. Geojournal, 2(2): 117-122.

Mccalla R J, 1983. Separation and specialization of land uses in cityport waterfronts: The cases of Saint John and Halifax. Canadian Geographer, 27(1): 48-61.

Merkel A, 2017. Spatial competition and complementarity in European port regions. Journal of Transport Geography, 61(1): 40-47.

Morgan F W, 1958. Ports and Harbors. London: Hutchison Press.

Mou N X, Liao M D, Zhang H C et al., 2018a. Evaluation on location advantages of the ports along the Maritime Silk Road. Journal of Geo-Information Science, 20(5): 613-622. (in Chinese)

Mou N X, Liu C X, Zhang L X et al., 2018b. Spatial pattern and regional relevance analysis of the Maritime Silk Road shipping network. Sustainability, 10(4): 977.

Moura T G Z, Garcia-Alonso L, Salas-Olmedo M H, 2017. Delimiting the scope of the hinterland of ports: Proposal and case study. Journal of Transport Geography, 65(1): 35-43.

Omiunu F G I, 1989. The port factor in the growth and decline of Warri and Sapele townships in the western Niger Delta region of Nigeria. Applied Geography, 9(1): 57-69.

Páez A, Scott D M, Morency C, 2012. Measuring accessibility: Positive and normative implementations of various accessibility indicators. Journal of Transport Geography, 25(9): 141-153.

Patton D J, 1958. General cargo hinterlands of New York, Philadelphia, Baltimore, and New Orleans. Annals of the Association of American Geographers, 48(4): 436-455.

Peng B, 2013. Port locational potential evaluation and development strategy research on Zhoushan islands new district: Based on empirical analysis of Zhoushan, Ningbo and Shanghai Port locational potential. Economic Geography, 33(6): 114-118, 131. (in Chinese)

Peng P, Cheng S F, Chen J H et al., 2018a. A fine-grained perspective on the robustness of global cargo ship transportation networks. Journal of Geographical Sciences, 28(7): 881-899.

Peng P, Yang Y, Lu F et al., 2018b. Modelling the competitiveness of the ports along the Maritime Silk Road with 
big data. Transportation Research Part A: Policy and Practice, 118(1): 852-867.

Raimbault N, 2019. From regional planning to port regionalization and urban logistics. The inland port and the governance of logistics development in the Paris region. Journal of Transport Geography, 78(1): $205-213$.

Robards M, Silber G, Adams J et al., 2016. Conservation science and policy applications of the marine vessel Automatic Identification System (AIS): A review. Bulletin of Marine Science, 92(1): 75-103.

Sun Z, Zheng J, 2016. Finding potential hub locations for liner shipping. Transportation Research Part B: Methodological, 93(Part B): 750-761.

Taaffe E J, Morrill R L, Gould P R, 1963. Transport expansion in underdeveloped countries: A comparative analysis. Geographical Review, 53(4): 503-529.

Tadić S, Krstić M, Brnjac N, 2019. Selection of efficient types of inland intermodal terminals. Journal of Transport Geography, 78(1): 170-180.

Tambo E, Khayeka-Wandabwa C, Muchiri G W et al., 2019. China's Belt and Road Initiative: Incorporating public health measures toward global economic growth and shared prosperity. Global Health Journal, 3(2): 46-49.

Viljoen N M, Joubert J W, 2016. The vulnerability of the global container shipping network to targeted link disruption. Physica A: Statistical Mechanics and Its Applications, 462(1): 396-409.

Wang C J, 2008. Research progress and prospects of modern port geography. Advances in Earth Science, 23(3): 243-251. (in Chinese)

Wang C J, Chen P R, Chen Y H, 2018b. The identification of global strategic shipping pivots and their spatial patterns. Journal of Geographical Sciences, 28(9): 1215-123.

Wang J H, Deng Y, Song C et al., 2016a. Measuring time accessibility and its spatial characteristics in the urban areas of Beijing. Journal of Geographical Sciences, 26(12): 1754-1768.

Wang L, Goodchild A, Wang Y, 2018a. The effect of distance on cargo flows: A case study of Chinese imports and their hinterland destinations. Maritime Economics \& Logistics, 20(3): 456-475.

Wang L H, Zhu Y, 2017. The evolution of China's international maritime network based on the "21st Century Maritime Silk Road". Acta Geographica Sinica, 72(12): 2265-2280. (in Chinese)

Wang N, Wu N, Dong L et al., 2016b. A study of the temporal robustness of the growing global container-shipping network. Scientific Reports, 6(1): 1-10.

Wang Z, Xu G, Bao C et al., 2017. Spatial and economic effects of the Bohai Strait Cross-Sea Channel on the transportation accessibility in China. Applied Geography, 83(1): 86-99.

$\mathrm{Xu} \mathrm{M,} \mathrm{2004.} \mathrm{The} \mathrm{new} \mathrm{development} \mathrm{of} \mathrm{contemporary} \mathrm{western} \mathrm{location} \mathrm{choice} \mathrm{theories:} \mathrm{From} \mathrm{classical} \mathrm{location}$ theory to neoclassical location theory. Journal of Guizhou College of Finance and Economics, (5): 71-75. (in Chinese)

Xu M D, Wang S, 2009. Analysis on the location advantage value based on road and towns. World Regional Studies, 18(4): 91-99. (in Chinese)

Yang L B, Zou B, Huang Y P et al., 2008. Quantitative analysis of the development level of China's provincial comprehensive transportation. Economic Geography, 28(2): 279-282. (in Chinese)

Yang W Y, 1997. Higher Economic Geography. Beijing: Peking University Press.

Zhao C, Jensen J, Zhan B, 2017. A comparison of urban growth and their influencing factors of two border cities: Laredo in the US and Nuevo Laredo in Mexico. Applied Geography, 79(1): 223-234.

Zhou N, Hao J M, Xing T T et al., 2012. The spatial configuration of transport superiority in Huang-Huai-Hai Plain. Economic Geography, 32(8): 91-96. (in Chinese) 